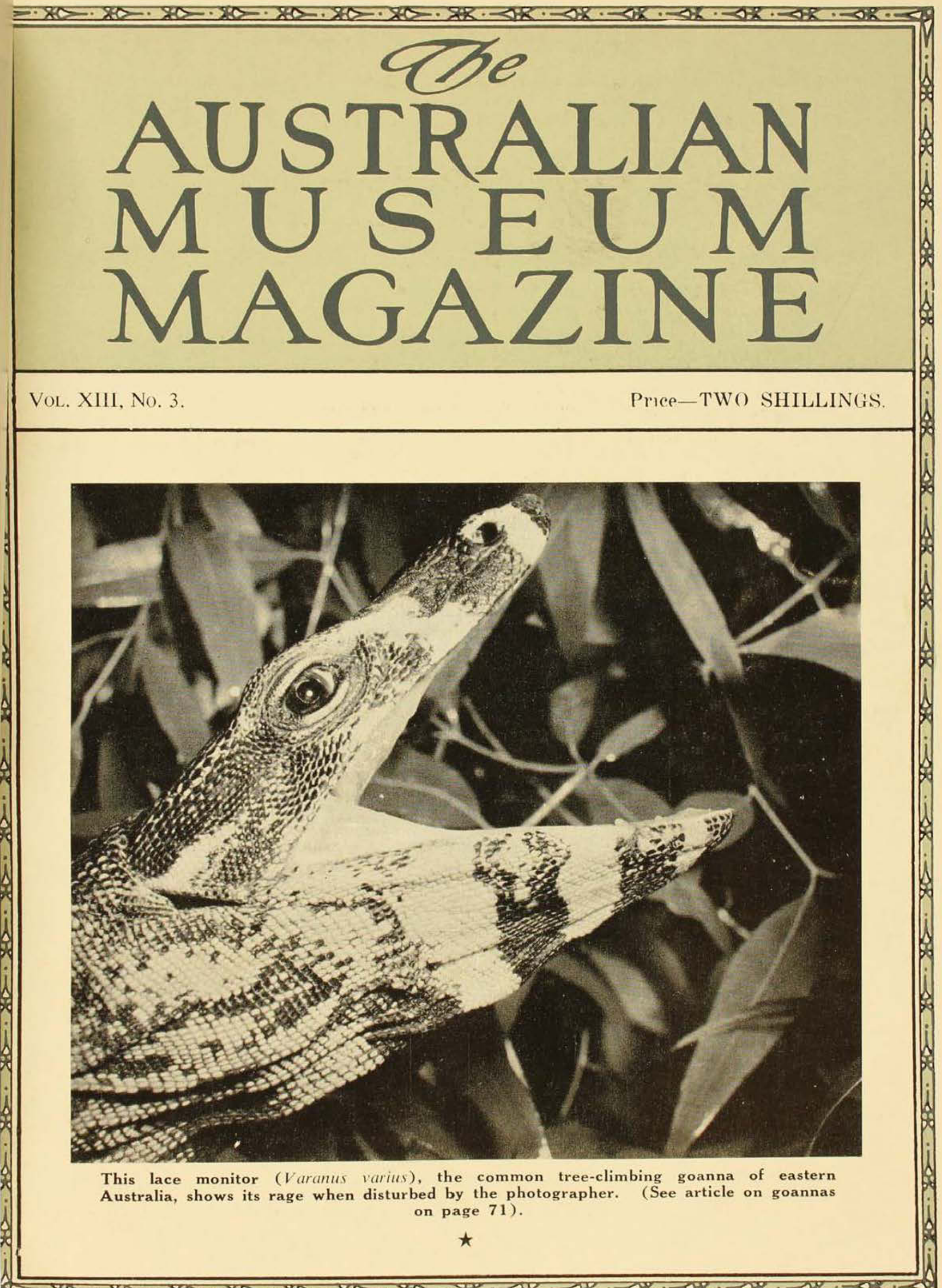

This lace monitor (Varanus varius), the common tree-climbing goanna of eastern Australia, shows its rage when disturbed by the photographer. (See article on goannas 


\title{
THE AUSTRALIAN MUSEUM
}

HYDE PARK, SYDNEY

\section{B OARD OF TRUSTEES}

\author{
PRESIDENT: \\ WALLACE C. WURTH, C.M.G., LL.B., Hon. LL.D. \\ CROWN TRUSTEE: \\ F. B. SPENCER. \\ OFFICIAL TRUSTEES: \\ THE HON. THE CHIEF JUSTICE. \\ THE HON. THE PRESIDENT OF THE LEGISLATIVE COUNCIL. \\ THE HON. THE CHIEF SECRETARY. \\ THE HON. THE ATTORNEY GENERAL. \\ THE HON. THE TREASURER. \\ THE HON. THE MINISTER FOR PUBLIC WORKS. \\ THE HON. THE MINISTER FOR EDUCATION. \\ THE AUDITOR-GENERAL. \\ THE PRESIDENT OF THE NEW SOUTH WALES MEDICAL BOARD. \\ THE SURVEYOR-GENERAL AND CHIEF SURVEYOR. \\ THE CROWN SOLICITOR.
}

\section{ELECTIVE TRUSTEES :}

O. G. VICKERY, B.E., M.I.E. (Aust.). WALLACE C. WURTH, C.M.G., LL.B. PROF. A. P. ELKIN, M.A., Ph.D.

F. MCDOWELL.

R. J. NOBLE, C.B.E., M.Sc., Ph.D.

E. J. KENNY, M.Aust. I.M.M.

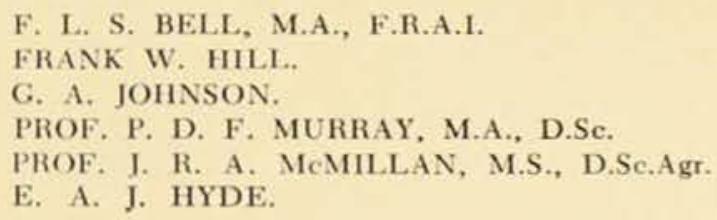

\section{DIRECTOR :}

J. W. EVANS, Sc,D.

DEPUTY DIRECTOR :

H. O. FLETCHER, M.Sc.

SCIENTIFIC STAFF :

Birds, Reptiles and Amphibians: J. A. KEAST, M.A., M.Sc., Ph.D., Curator; H. G. COGGER, B.Sc. (Gen. Sc.), Assistant Curator.

Mammals: B. J. MARLOW, B.Sc., F.Z.S., Curator.

Fishes: G. P. WHITLEY, F.R.Z.S., Curator.

Insects and Arachnids: D. K. McALPINE, M.Sc., Assistant Curator,

Molluscs: D. F. McMICHAEL, M.A., Ph.D., Curator.

Crustacea and Coelenterates: F. A. McNEILL, Curator.

Worms and Echinoderms: ELIZABETH C. POPE, M.Sc., Curator.

Minerals and Rocks: R. O. CHALMERS, A.S.T.C., Curator.

Fossils: H. O. FLETCHER, M.Sc., Curator.

Anthropology: F. D. McCARTHY, Dip.Anthrop., Curator.

EDITORIAL ASSISTANT AND PUBLIC RELATIONS OFFICER: PETER COLLIS.
EDUCATION OFFICER :

PATRICIA M. MeDONALD, B.Sc., Dip.Ed.

$$
\begin{gathered}
\text { EXHIBITION DEPARTMENT, } \\
\text { ART AND DESIGN SECTION: } \\
\text { F. J. BEEMAN. }
\end{gathered}
$$

LIBRARIAN:

MARY DAVIES, B.Sc., L.A.A.
PREPARATION SECTION: R. B. MACKAY.
PHOTOGRAPHER AND VISUAL AIDS OFFICER: H. HUGHES.

\section{HONORARY SCIENTIFIC STAFF :}

Zoologists.

E. A. BRIGGS, D.Sc.

H. LEIGHTON KESTEVEN, D.Sc,, M.D.

MELBOURNE WARD, F.R.Z.S., F.Z.S.

TOM IREDALE.

A. J. MARSHALL, D.Sc., D.Phil.

Ornithologist.

K. A. HINDWOOD, C.F.A.O.U., F.R.Z.S.
JOYCE ALI.AN, F.R.Z.S.

S. J. COPLAND, M.Sc.

ELLIS TROUGHTON, F.R.Z.S.

A. A. RACEK, Dr, rer, nat. (Brno).

Philatelist.

FRANK W. HILL 


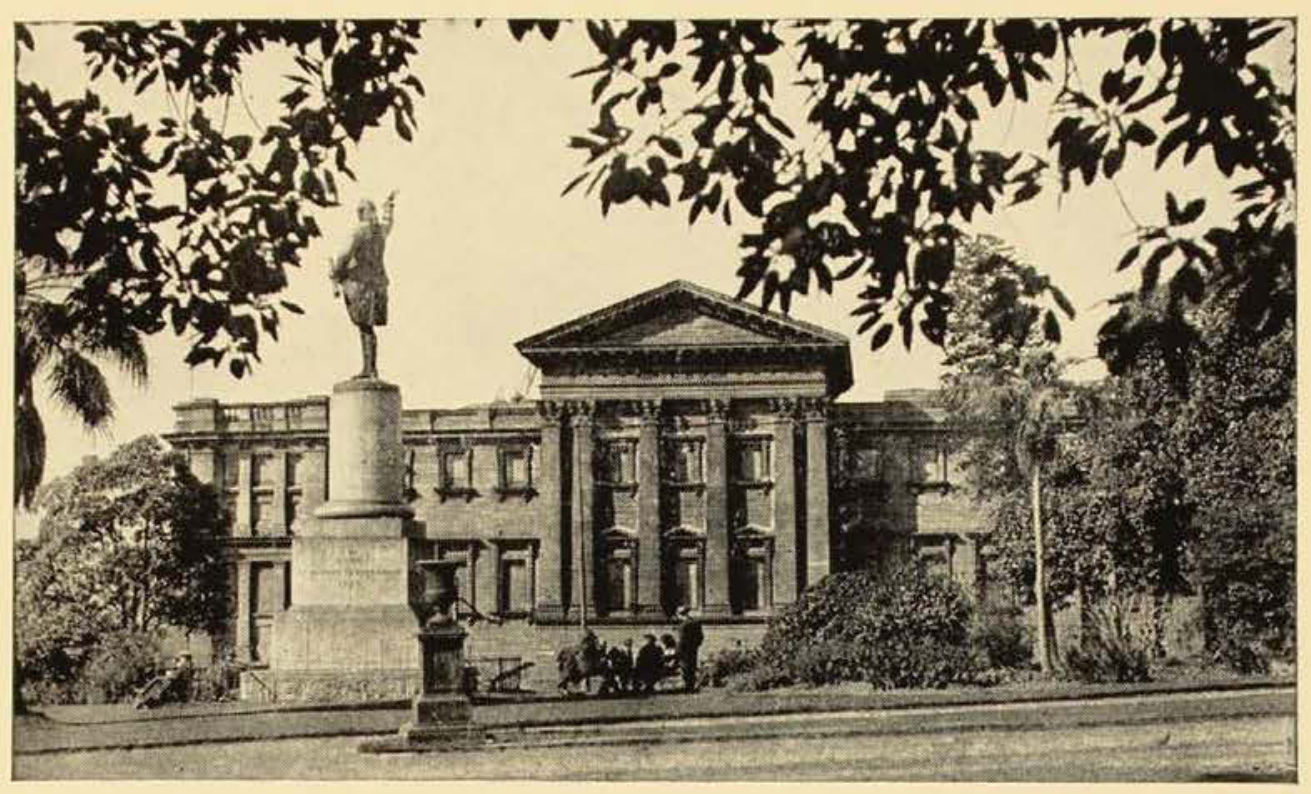

\section{THE AUSTRALIAN MUSEUM MAGAZINE}

Page

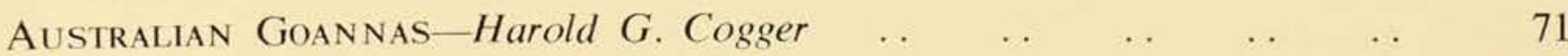

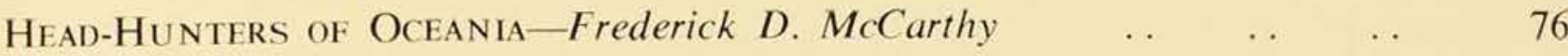

Relict Animals and Plants of the Macdonnell Ranges-Allen Keast 81

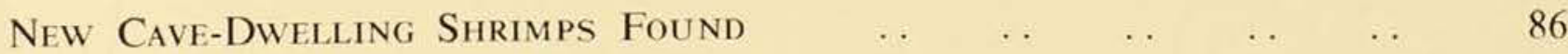

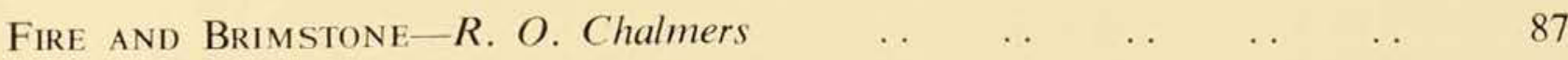

$\begin{array}{lllllllllllll}\text { NOTES AND NEWS } & \ldots & \ldots & \ldots & \ldots & \ldots & \ldots & \ldots & \ldots & \ldots & 89\end{array}$

These Shellfish are GoOd to Eat-Donald F. McMichael $\quad \ldots \quad \ldots \quad 90$

A Museum Expedition to the Hamersley Range- $\boldsymbol{W}$. D. $\boldsymbol{D}$. L. Ride $\quad . \quad 94$

The Way of Liff of the Slater_J. Le Gay Brereton _ . $\quad \ldots \quad \ldots \quad \ldots$

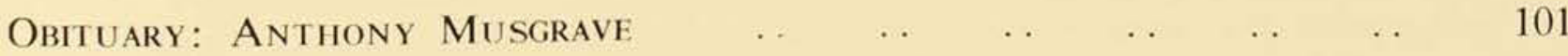

OUR FRONT COVER-This photo of a lace monitor was taken by Harold G. Cogger, Assistant Curator of Reptiles and Amphibians at the Australian Museum, whose article on Australian goannas appears on page 71. When angered, as in the cover picture, the lace monitor will rear up, with mouth agape, threshing its tail and hissing loudly.

VOLUME XIII. NUMBER 3. 


\section{RECENT BOOKS}

\section{COUNTRY OF THE DEAD \\ by Lyndon Rose}

An unusual, compelling first novel, set in the harsh desert of Central Australia. It tells of a manhunt for an old aboriginal murderer who killed to defend his tribe's customs, and the effect this had on a half-caste boy torn between the white and the black man's world.

$17 / 6$ (post $7 d$.)

\section{AUSTRALIAN CRICKET: A HISTORY}

by A. G. ("Johnnie") Moyes

A complete picture of cricket in Australia, past and present, by the expert best qualified to give it. He conveys an amazing amount of information, and writes with wit and humour of our cricket greats, from Spofforth to Benaud. 48 pages of old and new photographs. $50 /-($ post $1 / 1)$

\section{SAMMY ANDERSON, COMMERCIAL TRAVELLER by H. D. Williamson}

Sammy and his breezy, down-to-earth friends and rivals are always good company, whether making themselves comfortable in an express train or meeting in a country pub, and their triumphs and disasters provide very entertaining reading. $20 /-($ post 7 d.)

\section{AUSTRALIA ASTRIDE}

by Des Martin

Horses and horsemanship in Australia-for show riders, jockeys, bushmen, professionals, amateurs, old-timers and youngsters-are fully covered in this practical guide, based on the author's extensive experience in riding, training and breeding horses. 16 pages of photographs.

$25 /-($ post 9 d.)

\section{DUET FOR THREE HANDS \\ by Cyril Smith}

The frank life story of a famous English pianist who, when his left arm was paralysed, refused to believe doctors who said he could never play again. $\mathrm{He}$ and his equally talented wife are now playing "duets for three hands" in the world's capitals. Photographs.

$22 / 6$ (post 10d.)

\section{MUSIC FOR MOHINI \\ by Bhabani Bhattacharya}

"Conflict between ancient traditions and emancipation in modern India is the the background of Music For Mohini-an interesting, touching and delightful novel ... presents a fascinating picture of village life and customs." (Brisbane Telegraph) $17 / 6$ (post $10 \mathrm{~d}$.)

\section{At all booksellers and ...}

\section{Angus \& Robertson Ltd., 89 Castlereagh Street, Sydney}




\title{
THE AUSTRALIAN MUSEUM MAGAZINE
}

Published Quarterly by the Australian Museum College Street, Sydney

Editor: J. W. Evans, Sc.D.

Annual Subscription, Posted, 9/-

Vol. XIII, No. 3

September 15,1959

\section{Australian Goannas}

\author{
By HAROLD G. COGGER
}

FEW reptiles have become as prominent in their country's language and folklore as the Australian goanna. The name goanna is to be heard in many colloquial phrases used by people throughout the country, and the number of bushman's yarns about this animal and its habits almost outnumber those about the kangaroo.

Of the world's 25 or so species of goannas (Family Varanidae), which are found in various parts of Africa, Asia and through the Indo-Malayan Archipelago to New Guinea and Australia, 18 are currently recognised as occurring on the Australian mainland. All living members of the family belong to the genus Varanus, which includes the largest living lizards. Although at least one species is to be found almost anywhere on the Australian continent, most occur in the dryer inland regions.

What is the origin of the word goanna? It is generally agreed that it is a corruption of the name "iguana", which was applied by the early settlers to this group of largish lizards because of a supposed resemblance to the true iguanas of the Americas, Madagascar and Fiji. However, the name goanna has now become a fixture in Australia, although it is not used outside this country.
Most foreign species are generally called "monitor lizards", and this term is often applied to some of our own forms, for example, the common "lace monitor".

Although there are characteristics in different goannas which are adaptations to particular ways of life, certain features are common to all members of the family. All are equipped with strong claws and limbs (in comparison with other lizard families) and the tail, though long and slender, is very powerful. In most species the tail is laterally compressed (flattened vertically) to a greater or lesser extent, though a few forms have an almost round tail. When the tail is broken it cannot be regrown, as in most geckoes, legless lizards and skinks. The tongue is very snake-like in that it is long, thin and forked, and is protruded to its full extent, flickering rapidly.

\section{Streamlined}

The whole animal is more or less streamlined, for the head is wedge-shaped and narrow, while the body, too, is fairly slender. However, older specimens are sometimes found with enormous girths due to layers of fat in the body wall, and it is evident from observations on such animals that 


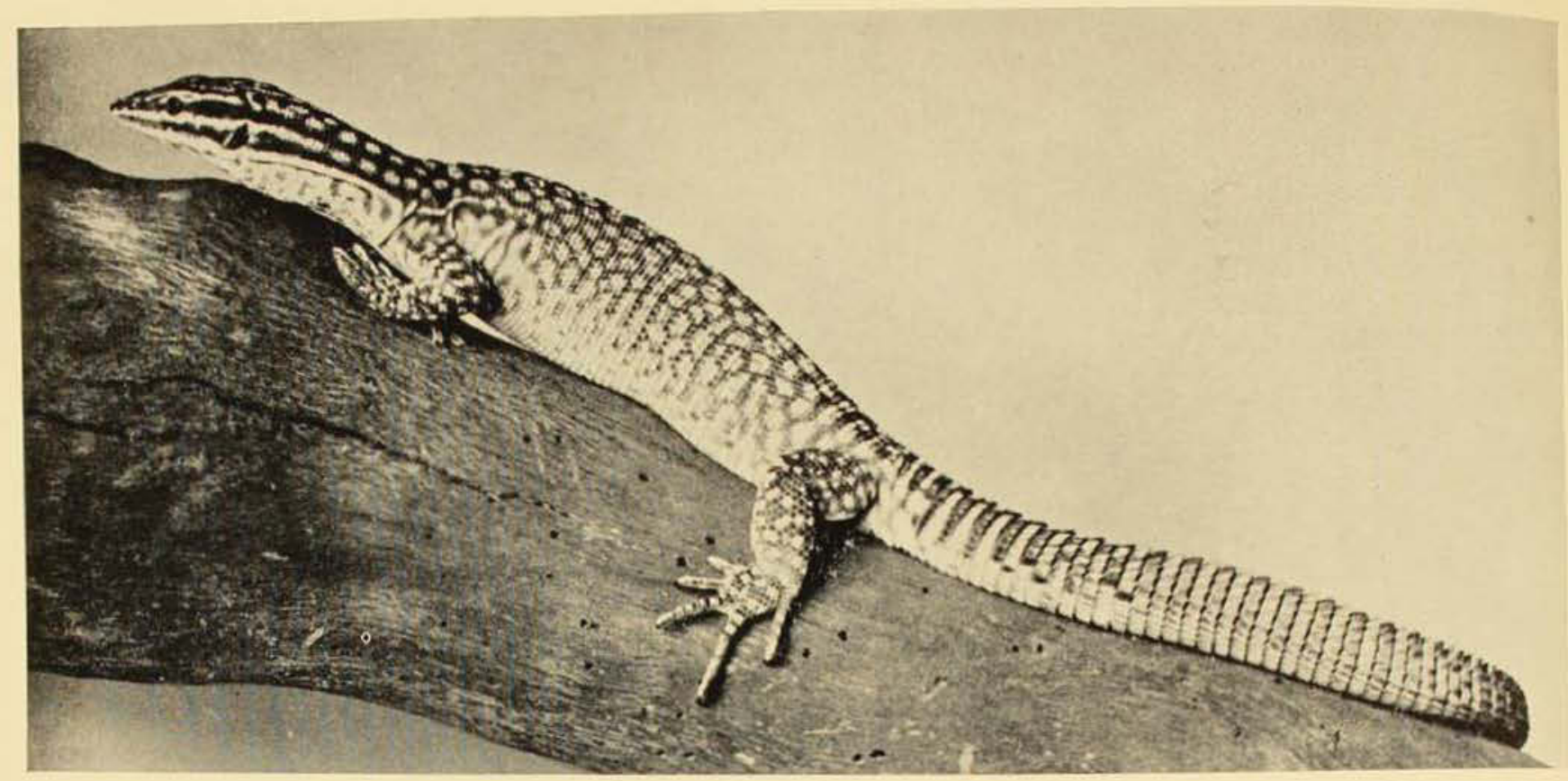

The spiny-tailed goanna (Varanus acanthurus) grows to a length of about $2 \mathrm{ft}$. It is found in many parts of northern Australia.

Photo.-Author.

this increase in body size and weight considerably reduces their speed and thus exposes them to a greater risk of attack. Nevertheless, their greater size may possibly compensate for their reduced manoeuvrability.

The teeth in all goannas are numerous and very sharp, and should be treated with caution. They are slightly recurved (bent backwards), so that it is difficult for prey to escape once caught in the powerful jaws.

Although goannas normally walk on all four legs they sometimes have the habit, when pursued, of folding the front legs along the side of the body and running only on the hindlimbs; in doing so, the forward part of the body is raised from the ground and, in extreme cases, the body is actually held almost vertically.

\section{Three Groups of Australian Goannas}

Australian goannas can be broadly divided into three groups - arboreal or treeclimbing goannas, terrestrial or grounddwelling goannas and aquatic goannas. The second group contains the largest number of species.

Typical of the first group is the lace monitor (Varanus varius), a form found throughout the eastern part of the continent and quite common on the outskirts of Sydney. It grows to more than $6 \mathrm{ft}$. in length, and when disturbed makes for the nearest tree. If any other upright object is handy (be it a man or horse) the undiscriminating goanna accepts it as a ready substitute and will attempt to climb to its top. Unless badly scared the goanna usually climbs only a few feet from the ground, but on the side of the tree away from its adversary, and if approached will move upward with a speed depending upon the speed of its pursuer, always keeping the tree between itself and its aggressor. Hence, if an attempt is made to keep the lizard in sight it executes an upward spiral movement around the trunk of the tree.

Although rarely at home on the ground, Varanus varius can show an amazing turn of speed and alacrity when no tree is present. If cornered it will raise itself high on its legs, inflate its body with air and stand at bay with mouth agape and threshing tail. at the same time producing a prolonged. loud, hissing noise. The tail of a large specimen is powerful enough to throw a man off balance, and can be quite painful on a bare leg or arm. This defence posture is typical of most goannas, large or small.

Another species which should perhaps be mentioned here, though possibly belonging strictly to the next group, is the perentic (Varanus giganteus) of Central Australia. This is the largest of the Australian 
goannas, growing to more than $8 \mathrm{ft}$. in length. Normally living in burrows, particularly about rocky outcrops, the perentie will take to a tree if hard-pressed.

Of the second, or ground-dwelling, group of goannas, the most common is Gould's monitor (Varanus gouldi), a species found throughout most parts of Australia. It will occasionally climb trees, but only as an extreme measure, for most of its life is spent on the ground. Although it is able to excavate burrows itself, it is generally found to inhabit both used and unused rabbit warrens or hollow logs, and rarely wanders any great distance from such cover. It is very agile and fast, and it is often difficult for the human eye to follow the swift movement and rapid changes in direction of a Gould's monitor in flight.

The colour of this species varies tremendously throughout its range, but it is almost invariably found to have a black stripe running through the eye, while the tip of the tail is white for the last few inches of its length.

There are a number of other terrestrial goannas, most of which inhabit the more arid regions of the continent. One which is worthy of mention is the spiny-tailed goanna (Varanus acanthurus), a smaller species growing to about $2 \mathrm{ft}$. in length, which is found throughout many parts of northern Australia and which is characterised by rows of enlarged, backwardly-directed, spiny scales around the tail. This lizard is commonly found around rocky outcrops, where it shelters in fissures and cavities in the rock. The spines catching on the rock surface make it difficult for an enemy to pull the lizard from such retreats.

This species is one of the few goannas which are known to be cannibalistic, and on one occasion, when several were sent to the Australian Museum in a single container, the only occupant on arrival was the largest specimen, considerably healthier than when it had been consigned.

\section{Aquatic Species}

There are two goannas which merit attention because of their aquatic habits.

The first, Varanus salvator, is a relatively rare form in Australia, for, although common throughout the Indo-Malayan Archipelago, it is found only occasionally on Cape York Peninsula.

The second aquatic monitor, Varanus mertensi, is found in the Kimberley district of Western Australia. Its tail is compressed vertically to provide an effective paddle when swimming, at which time its legs are held along its body to lower resistance to the water. Its nostrils are on the top of the snout (instead of on the side, as in other species) and are supplied with small flaps of skin which act as valves to seal off the respiratory passages when the lizard is submerged. The nostrils on the top of the snout allow the goanna to float in the water and breathe with only the tip of the snout projecting above the surface.

Although, apart from the aquatic species, goannas rarely enter the water, they are all powerful swimmers.
The lace-monitor (Varanus varius). found in most parts of eastern Australia, grows to more than $6 \mathrm{ft}$ in length. When disturbed it usually makes for the nearest tree.

Photo-Author.

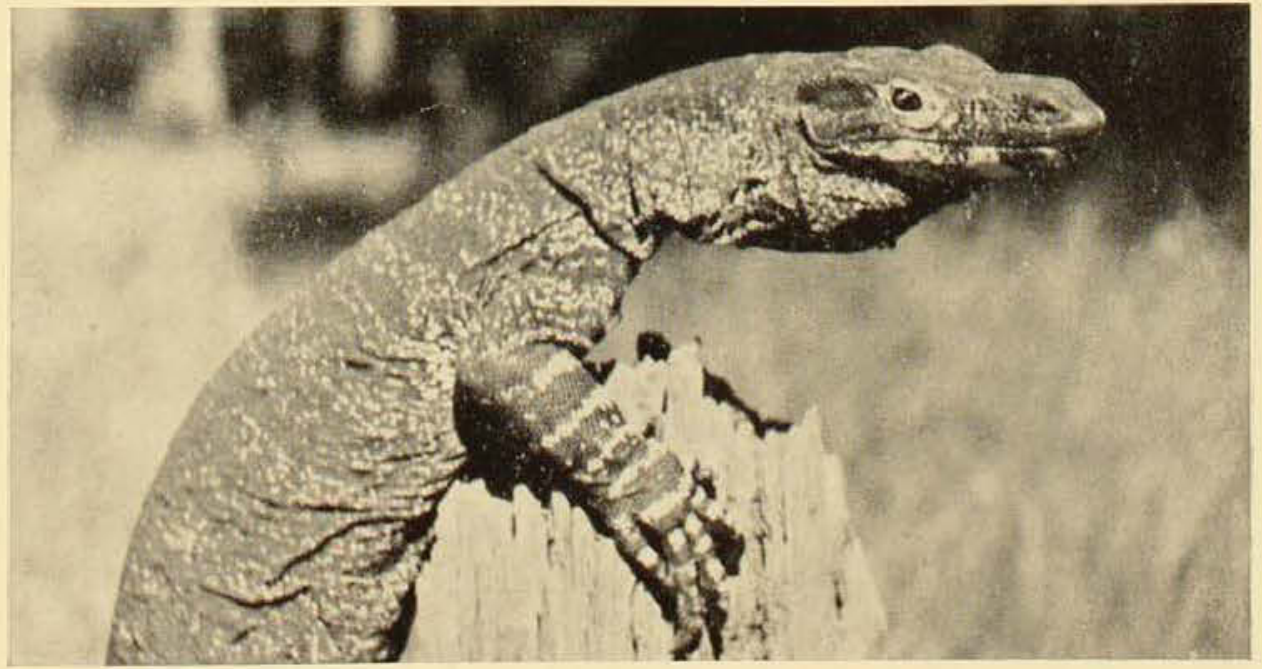




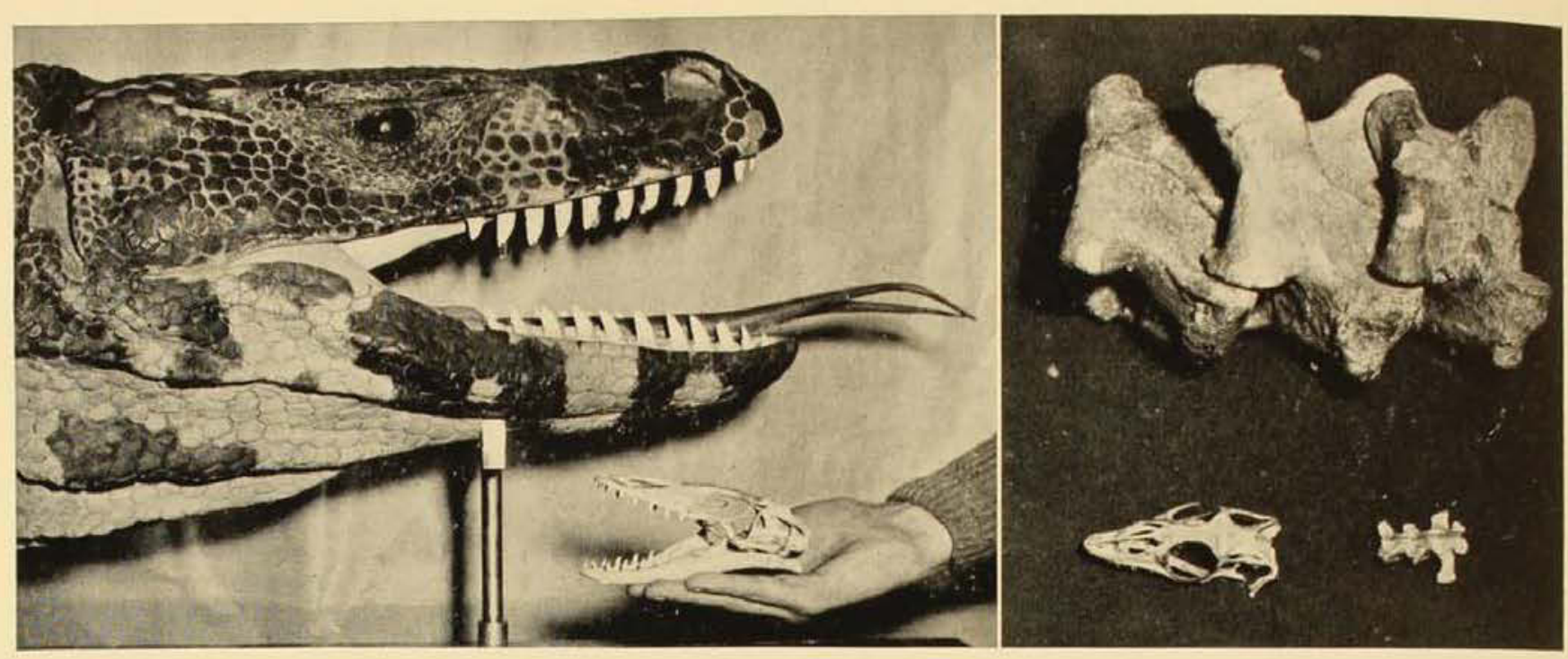

Left: A reconstruction of the head of the extinct giant goanna Megalania, which grew to more than $20 \mathrm{ft}$. in length. The skull held in the hand is that of a $6 \mathrm{ft}$. contemporary goanna. Right: The skull and three vertebrae of a $4 \mathrm{ft}$. goanna are dwarfed by three vertebrae of Megalania.

Photos.-Author.

To what size do goannas grow? The largest known living example is the Komodo dragon (Varanus komodoensis), which is found only on several islands in the Lesser Sundas in Indonesia, namely, those of Komodo, Flores and Ringa. Although reports of Komodo dragons more than $20 \mathrm{ft}$. long have been received, it is exceedingly doubtful whether they ever reach a length of more than $12 \mathrm{ft}$ or $13 \mathrm{ft}$.

As previously mentioned, the largest living Australian goanna is the perentie, though most goannas reach only $4 \mathrm{ft}$. or $5 \mathrm{ft}$. in length. However, there are several so-called "pigmy" species which seldom exceed $2 \mathrm{ft}$.

\section{Huge Primaeval Goannas}

Australia can boast one of the largest varanids that ever lived. Fossil remains have been found in many parts of Australia of a large goanna known as Megalania prisca which, though sometimes claimed to have reached $30 \mathrm{ft}$. in length, probably did not exceed $20 \mathrm{ft}$. This, nevertheless, was a veritable giant among lizards by today's standards, although at the time it lived other giants, such as the wombat-like marsupial Diprotodon, which grew to a length of $15 \mathrm{ft}$., and the kangaroo Palorchestes, which stood more than $10 \mathrm{ft}$. high, were also to be found. These animals lived during the Pleistocene period (up to one million years ago), when, it is believed, Australia was much wetter and more forested than it is today.

Goannas eat a great variety of food, both living and dead. The lace monitor is well known for its raids on poultry runs, where it feeds both on the eggs and the fowls. This and other tree-climbing forms play havoc amongst small birds, and frequently raid their nests. Most species eat rats and mice (depending on their size), while the pigmy goannas and the young of the larger species eat insects such as grasshoppers. Cannibalism occurs in some species and many of the larger forms are known to feed at times on snakes. Aquatic species feed on fish, as well as the other foods mentioned.

Apart from this living food, many species eat carrion. For this reason, a bite from a goanna may easily become infected and should be treated with an antiseptic. The same applies to wounds inflicted by the claws, for these are often used to tear apart decaying flesh.

It is probably their liking for this food that has indirectly led to the popular myth that a goanna bite will cause a recurring sore, usually breaking out afresh once a year. This idea is probably derived from the fact that a very troublesome and often prolonged infection may result if a wound is not sterilised. Although this "old wives" tale" was originally applied only to the goanna, the present generation seems willing to apoly it to all large lizards. 
It should be clearly stated that no goanna is venomous, and provided treatment is given as mentioned above no trouble should be experienced.

All varanids are egg-layers, though the actual number laid is known only for a few species. The breeding season usually extends between September and November. The lace monitor lays up to 12 or more eggs, which are rather elongated, with a tough parchment-like shell. They average about 2 in. in length and are usually laid up to $6 \mathrm{in}$. or more below the surface in a hole excavated by the female. She covers them with soil. At the end of a period, which varies somewhat from species to species and from place to place, but which is believed to average about eight weeks, the young goannas cut their way out of the egg by means of a sharp "egg-tooth" on the tip of the snout. This tooth is lost soon after birth. The young then slowly make their way un through the soil, which may be partly softened by fluids from the broken egg, and on emerging are able to fend for themselves.

Heat from the sun is usually sufficient to warm the developing eggs, but additional heat may be supplied in a number of ways. For example, after excavating the egg chamber the female goanna scrapes the soil back into the hole. In doing so, she often rakes a considerable quantity of leaf-litter or grass into the hole with the soil, and, as this vegetable matter decays in the following weeks, heat is generated which assists in the incubation of the eggs.

\section{Eggs Laid In Termite Mounds}

Another breeding habit peculiar to some varanid species, including Varanus varius and Varanus gouldi, is that of burrowing into the centre of a termite mound. The eggs are then laid, the female emerging from the mound through her original burrow. The termite colony immediately sets to work to repair the damaged mound, so that within a relatively short time after the female's emergence the entrance is completely sealed up and the eggs may develop within the nest secure from most natural predators. Not only are they afforded such complete protection, but the temperature of the decaying wood within the mound is much higher than that outside and is relatively independent of daily fluctuations. Hence, the mound both protects and incubates the eggs.

Goannas are subject to predation by a variety of other animals. Depending on their size, they are eaten by large fish, other lizards, snakes, birds such as kookaburras, butcher birds, hawks and eagles, and by a number of mammals, including man, for natives consider goannas to be a delicacy and also eat their eggs. The introduced fox appears to be adept at finding nesting sites and disposing of the eggs.

As with other reptiles, goannas shed their skin at intervals which become longer as they grow larger. The skin is usually shed piecemeal, and at this time a goanna presents a very untidy appearance, with trailing flaps of loose skin hanging from its body.

Probably the commonest Australian goanna is the ground-dwelling Gould's monitor (V aranus gouldii). This species generally inhabits rabbit warrens and hollow logs, and rareiy climbs trees.

Photo-Allen Keast.

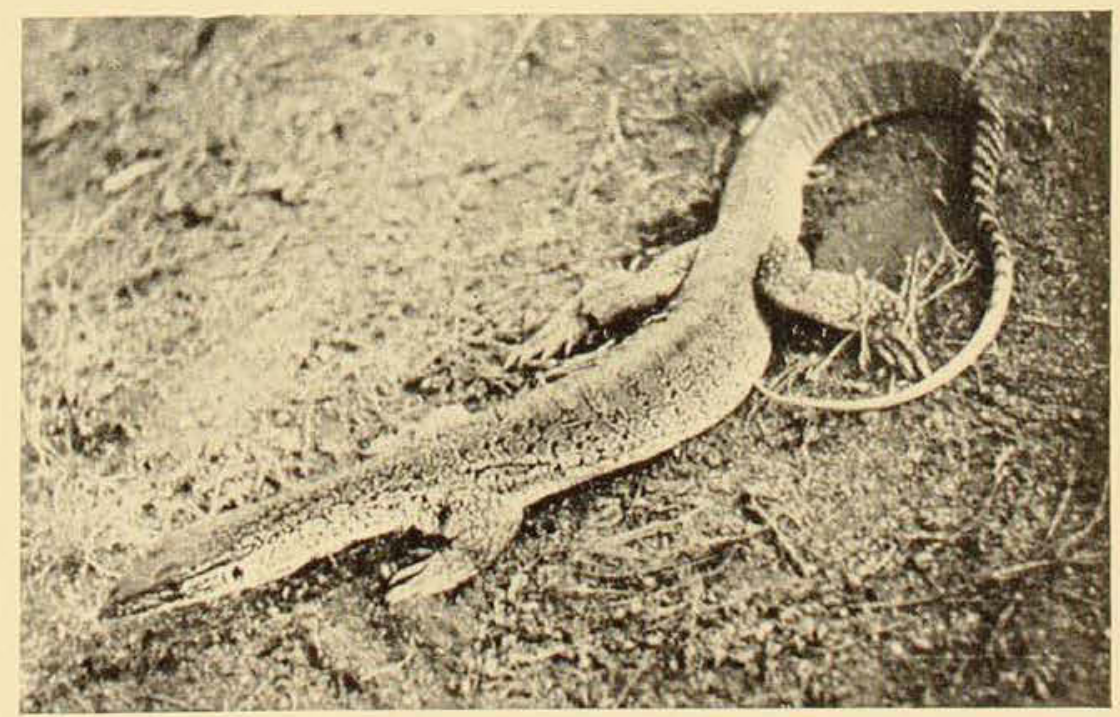




\section{HEAD-HUNTERS OF OCEANIA}

\section{BY FREDERICK D. McCARTHY}

THE scalping of enemies by the American 1 Indians and the cutting-out of the hearts of sacrificed slaves by the Incas of Peru were customs that have made a profound impression on Europeans because of the savagery associated with the need to fulfil a community's social and ritual obligations.

They are rivalled, if not overshadowed, by the horrors perpetrated by the headhunters of the Indonesian and Pacific Islands. These ruthless raiders, protected from danger by their magicians' rites, are known to have wiped out whole villages in one raid, and, over a period of years, to have entirely depopulated whole districts by this ghastly practice in which young and old of both sexes were the victims.

Head-hunting is part of a widespread belief which holds that the soul-matter, or spirit, of a human being not only pervades the whole body but is centred mainly in the head, the sanctity and importance of which are illustrated well by its enlargement in the human sculptures of Oceania and by taboos on the touching of a chief's head. An important aspect of this belief is that the continued reproduction and fertility of man, animals and plants are dependent on this soul-matter. It therefore became vital to a community to kill enemies and either eat their flesh or obtain their heads, or both, and so add their soul matter to the community's stock. The soul-matter of a victim was believed to be transferred to the captor or killer, and thus to his community.

\section{Beliefs About Head-trophies}

The Nagas of Assam believed that the possession of enemies' heads assured them of flourishing rice and other crops, caused animals to increase and effected the wellbeing of man, and that these good things would not happen without fresh heads.

Cannibalism, human sacrifice, head-hunting and other customs are manifestations of this basic belief, and other reasons for killing enemies were usually plentiful.

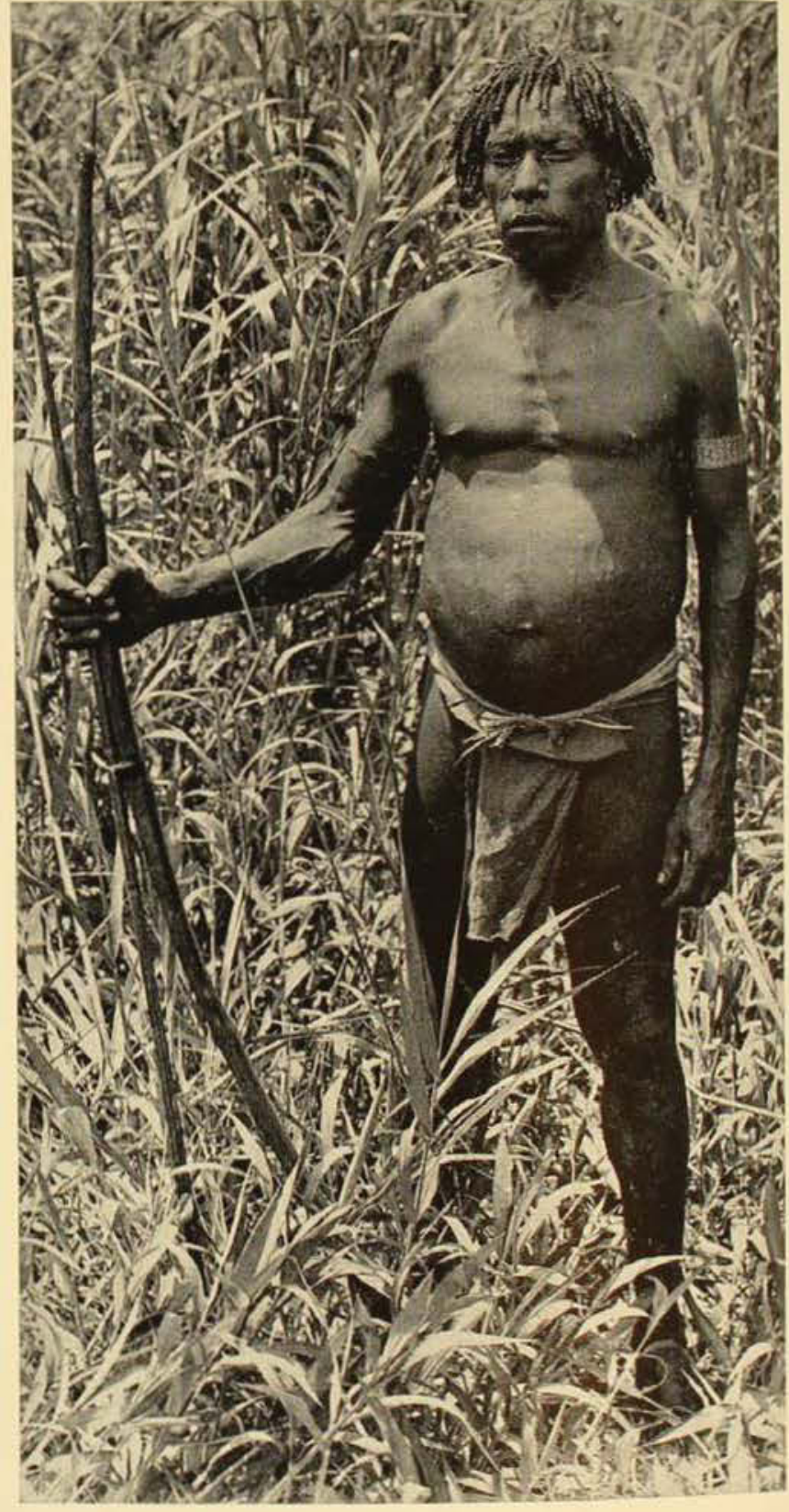

A warrior, armed with bow and arrow, from the Fiy River area, western Papua, photographed about 40 years ago, when head-hunting was being suppressed there.

Photo-Frank Hurley.

The Iban, a Mongoloid people of Sarawak, became fanatical head-hunters, and the men of their coastal villages were rewarded with heads by the crews of Malay ships which they joined in the plundering of seaside communities. The Iban warriors had 


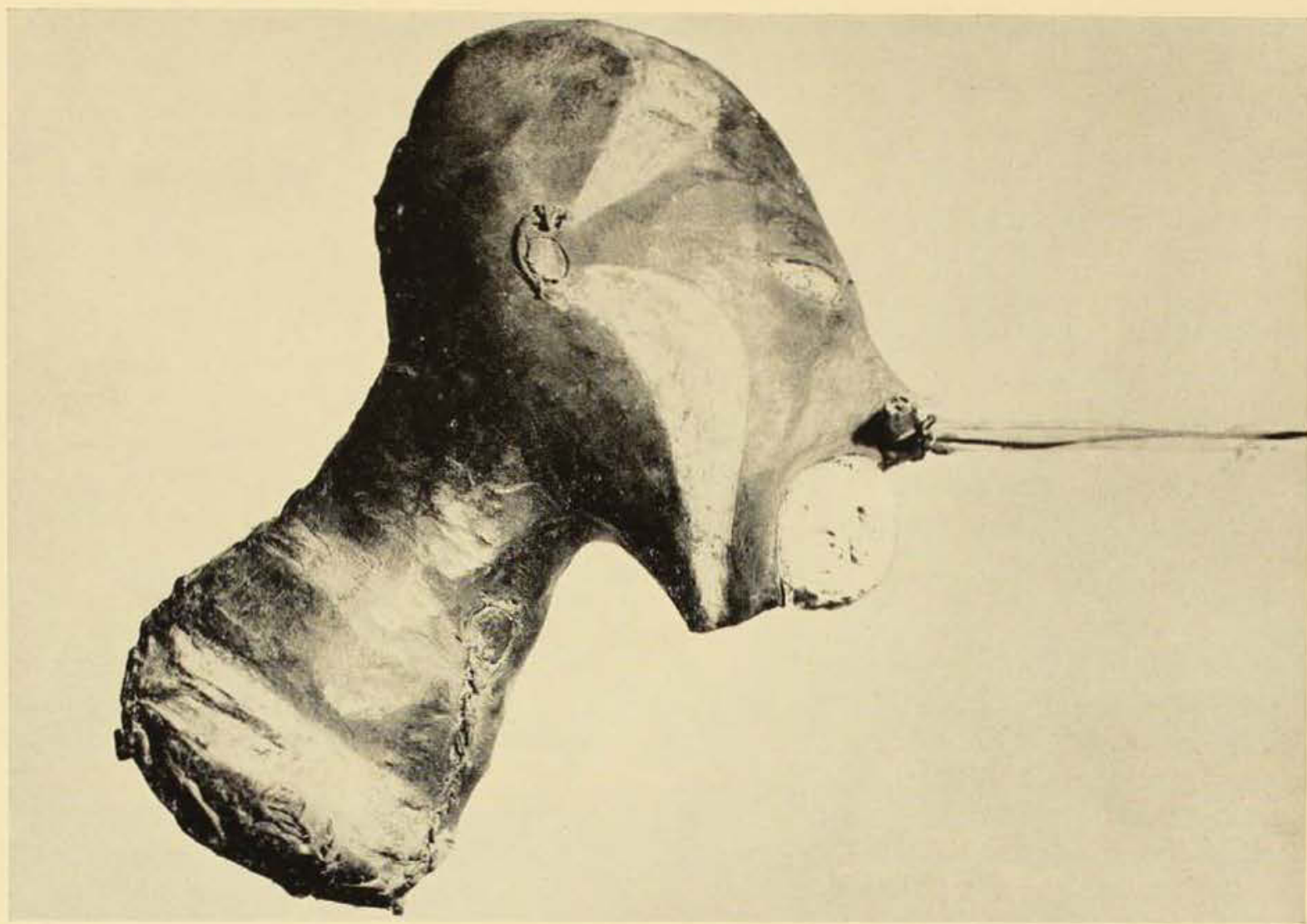

This head-trophy from the Lake Murray area, Fly River, western Papua, has a simple design in red and yellow painted on its black skin. Such heads were hung over house fires to protect them from insects.

Photo.-Howard Hughes.

other reasons to join in these dangerous ventures. The fresh supply of heads each year brought plentiful harvests and increased the number of animals in village and forest and fish in the rivers. It also warded off sickness, revenged insults, balanced feuds and sustained their hatred of their traditional enemies. It was a custom of their ancestors to be followed, and the victims were expected to become the slaves of the killers in the spirit world. A chief could not name his child or marry again after his wife's death, nor could the community go out of mourning after a chief's death, until fresh head-trophies were obtained. These were essential to establish the bravery and fighting ability of each generation of mena point of great importance to the women, who preferred to marry a proved headhunter. The rather ironic claim was made that their enemies, even though they lost their heads, ultimately became their killers' guardians and best friends.

Careful preparations were made for an Iban raid. A sequence of bird omens had to be favourable, and numerous taboos on personal behaviour and the utmost secrecy observed. Dressed in animal-skin coats and split-rattan hats, the warriors carried steelbladed swords and spears and wooden shields decorated with the hair of the slain. They kept a sharp look-out for ambushes both of their great canoes (up to $150 \mathrm{ft}$. long) on the river and of their party in the jungle, and scouts were sent ahead to observe the enemy's movements.

\section{Method of Attack}

At dawn of the selected day the attackers would set fire to their victims' longhouse apartment dwelling. The inmates would sound the alarm with drums in the house and defend themselves by throwing pointed clubs and spears at the raiders, who, however, captured them as they attempted to escape. The fiercest defenders were killed, and their heads and those of the wounded were cut off. The house was looted of its heads, bronze gongs and brassware before the fire spread too far. The attackers also 
took the heads of their own dead back with them, the bodies of the slain being left where they fell.

Sometimes the longhouse community was starved into submission, or the attackers accepted valuable objects to spare them, but no greater shame could be inflicted on the warriors than an unsuccessful raid, which not infrequently happened.

The successful raiders returned in great triumph and rejoicing with the heads (partially dried over a fire) which meant so much to their people. A series of ceremonies was then held: a head was hung on a pole beside a dead chief's tomb, and pieces of the victims' flesh were skewered to poles beside it as an offering to the omen birds; a dart was blown from a blowpipe towards the enemy's longhouse, and a fowl sacrificed to cleanse the village of sickness and make the men healthy and strong; the warriors enjoyed a feast of pigs, the lower jaws of which were hung on the chief's tomb; each of the head-trophies was carried into the longhouse by an old man or woman at the head of all the people, who marched up and down the verandah rejoicing; each family entertained its friends with a feast of pig and rice cakes, and, after a women's dance with the gruesome trophies, the latter were hung from a beam over the fires to preserve them.

Where several men participated in the final coup-de-grace the head was divided into portions as a reward to each of them.

\section{Heads Borrowed For Ceremonies}

In south-eastern Borneo, the skulls were elaborately carved and painted, but elsewhere they were merely smoke-dried. The power of enemies' heads is shown by the fact that when a longhouse community moved into a new residence they built a special hut to house old and discarded heads. This deceived the enemies' ghosts, still living in the skulls, into thinking they were being looked after instead of being abandoned. If this course were not taken the ghosts of the dead would inflict devastating harm on the community and its stock and gardens. It was not uncommon for the Iban to rob the tombs of their enemies for heads, and old ones were used, and even borrowed, for ceremonies when fresh ones were not available.

Another famous head-hunting centre was in southern New Guinea, from the western side of the Gulf of Papua across into Dutch New Guinea. Here lived the Wiram, Tugeri, Keraki, Semariji, Gambadi and Marind tribes, among others, in a region where the expectancy of life was extremely short and uncertain. The principal incentive for the raids in this area was to obtain the name of an enemy, male or female, to give to one's child. In this idea was embodied the link between the killer and his victim's soulmatter.

Such a name became the child's principal one, among many others, and to it great prestige attached. A man unable to give such a name to his child was shamed, and the child grew up lacking this badge of

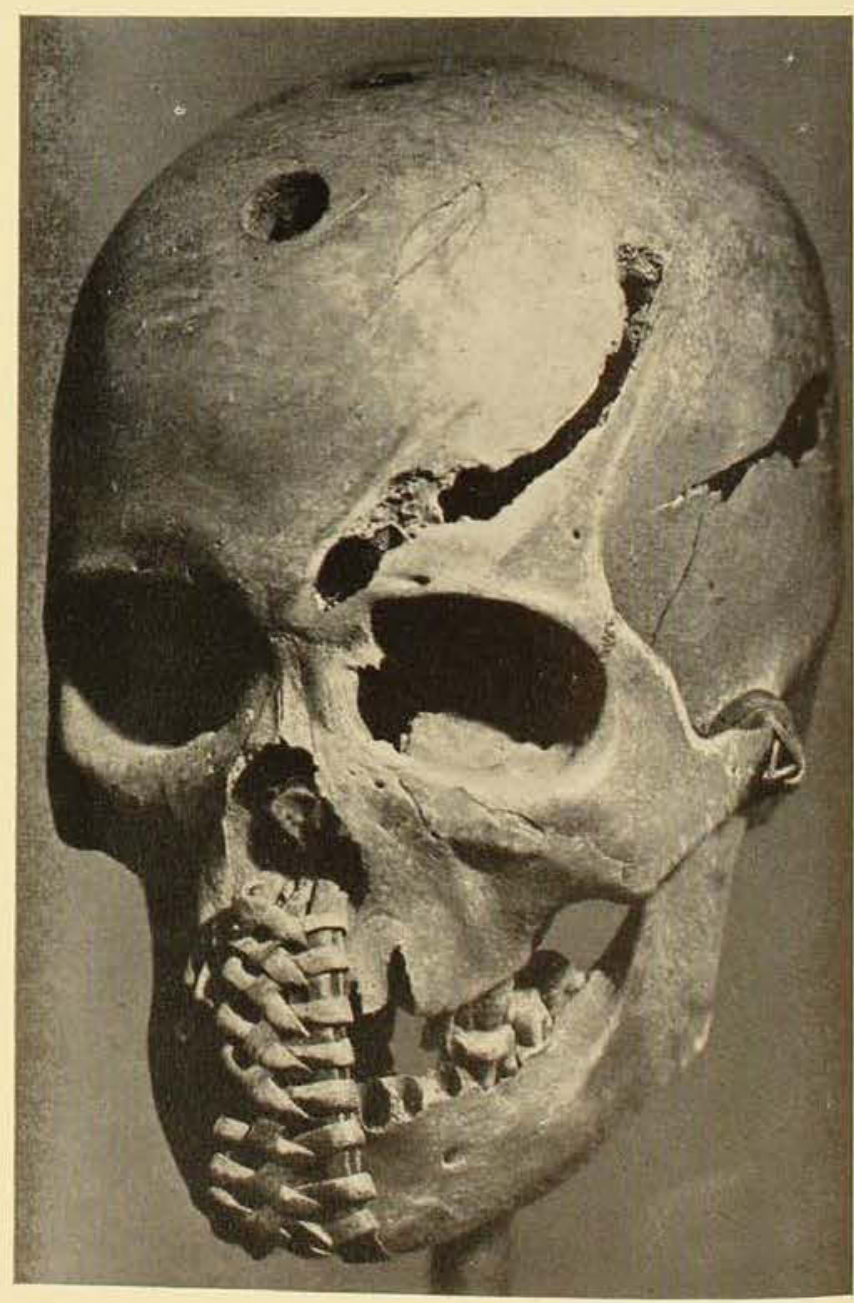

A head-trophy of the Ibans, a Mongoloid people of Sarawak. The two holes bored in the cranium were for the attachment of a carrying toggle.

Photo.-Howard Hughes. 


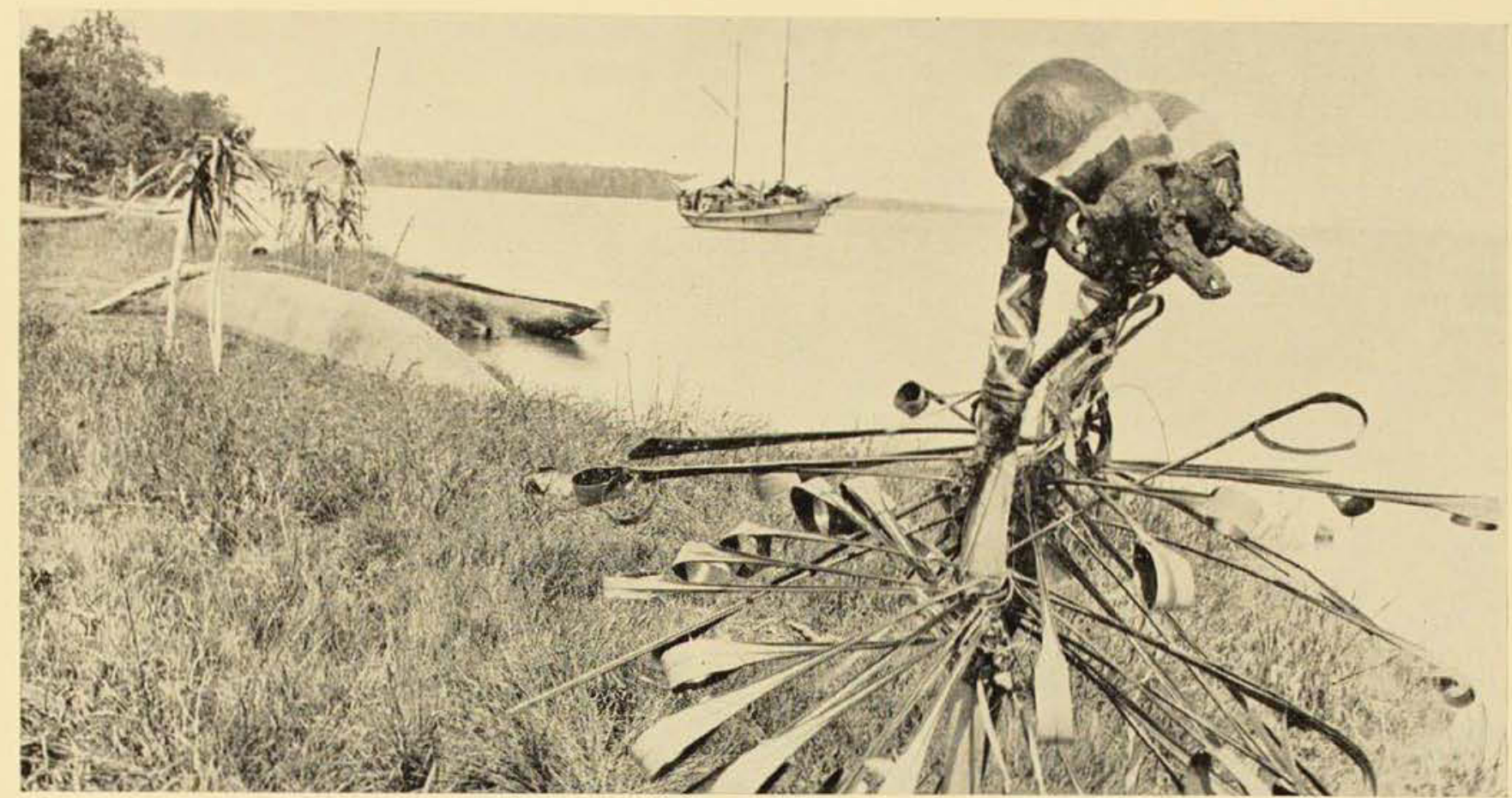

Head-trophies, with noses made of gum, displayed in front of a Goaribari village at Dopima, western Papua, for prestige and ritual purposes. Cowry shells represent the eyes.

Photo--Frank Hurley.

honour. The head names were used generation after generation. A head-hunter with names to spare either gave them as a great gift to a friend for an expected or recentlyborn baby, or bartered them for pigs and cther valuables.

The names were found out in various ways. Sometimes the victims were assembled in their village square and the children were forced to name them. All people over about 12 years of age were then slaughtered and beheaded. Sometimes the victims were ill-treated until they cried out a name, and this was taken as the head name. Scouts also learnt some of the names as they watched villagers' movements.

\section{New Guinea Raiders}

As with the Ibans, the warriors strongly desired to distinguish themselves, the women took pride in marrying a proved fighting man, successful raids balanced feuds and avenged insults, and the reward of the warriors for such raids was possession of the head-trophy. The lower jaw of a victim was highly valued. In arguments, a man would snatch such a thing from his string bag, lay it at the feet of his opponent and dramatically challenge him to match it - if he couldn't, he had no reply.
The New Guinea raiders followed the same pattern as the Iban. Taboos, omens and secrecy were observed, magic was employed to ensure success and render the enemy helpless, and the attack was made at dawn. Barbed arrows, finely carved and painted, were fired into the drowsy victims, who were struck down with stone-headed clubs in their huts.

It was a general practice for the raiders to strike some of the victims with a wand, hard enough to shatter its filigree carved head; the handle was carried back as a symbol of success. This wand was apparently part of the magic intended to stupefy the attacked villagers, but it also served to identify the raiders because the wand-heads were carved in distinctive village designs.

The hunters fired arrows into a tree above their head-trophies to chase the spirits back to the headless bodies of their owners. and returned in triumph to their own village, where they cooked the heads in ovens and ate a little of the flesh of the cheek or other part. Some men and women smeared the blood on their bodies. Women accompanied the raiders to take care of the young children captured. The final rite was a dance in which the warriors swung the grisly trophies slowly from side to side. The heads 
were finally hung over the fire-place in the owner's hut. So strong was the need and desire for heads and names that peace messengers were ambushed and visitors were treated with hospitality until their names were known, when they were killed.

\section{Solomon Islands Marauders}

The head-hunters of the central and western Solomons were also notorious. They carried their activities into the days of steel axes and rifles, and made vicious and merciless raids for the sole purpose of getting as many heads as they could. Originally, the heads were required for the opening of a new canoe-house, a highly sacred structure, the launching of a war or other large canoe, the funeral rites of chiefs and important people, and other ceremonies. In the raids prisoners were brought back to live a normal life in their captor's village until their heads were required for one of these purposes. A chief had law-breakers, rivals

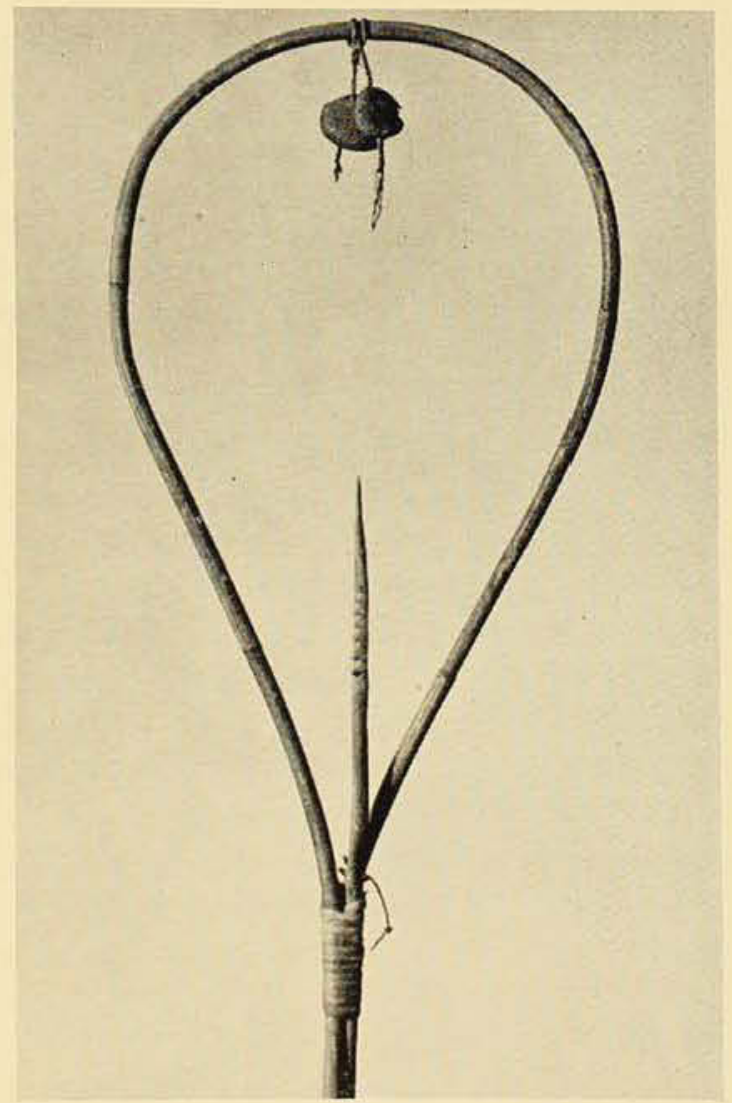

This "man-catcher" was used by headhunters of western Papua. The cane ring was placed over the victim's head, and the arrow-point, jabbing into the back of the neck, prevented attempts to escape.

Photo-_Howard Hughes. and those who aroused his hatred killed and their heads added to his collection. The friends of a murdered man would offer a large reward in shell-money for his killer's head, and these commissions were sometimes carried out by men whom we would regard as professional gangsters.

Canoe voyages of up to 135 miles were a feature of the Solomons raids. The New Georgia or Rubiana Island men raided villages on Florida, Malaita and Guadalcanar Islands, and no head was safe within 100 miles of Rubiana, where heaps of skull trophies were to be seen. The crew of a new war canoe had to "christen" it with fresh heads, which were smoke-dried and hung in the canoe-house or, on Florida Island, exposed on platforms.

\section{Huge Collections of Heads}

The constant demand for new heads caused the beheading of lone fishermen and hunters and small parties of gardeners. It even resulted in the taking of as many as 93 heads (seen by a Captain Cheyne in 1844) in a single raid by the Eddystone Islanders of the Solomons. Thirty to forty were commonly secured, and one census in Sarawak revealed that the longhouses each possessed from one to 100 or more, totalling thousands in the one district. Great piles of them were seen in some villages, sometimes in special huts, and the older insect-eaten and decayed ones were abandoned from time to time.

Apart from the ritual value of the practice, head-hunting bound the men of a community into fighting units, set standards of bravery and discipline for the youths to attain and compelled obedience to the chiefs and war leaders. Despite the uncertainty of life in head-hunting areas, the slaughtering of innocent people of all ages and the reign of terror in weaker villages, the suppression of head-hunting, like that of any major activity with manifold links with village life as a whole, contributed greatly to an initial decrease of natives in many areas. This was because such activities, closely bound up with their social and ritual life and forming part of annual cycles of great importance, became an absorbing interest which, when it was stopped, left a gap, mentally and physically, that could not be filled. 


\title{
Relict Animals and Plants of the Macdonnell Ranges
}

\author{
By ALLAN KEAST
}

\begin{abstract}
A MONG the most fascinating fields of study open to biogeographers and ecologists are those associated with populations of "relict" species of plants and animals. These are forms that are in the process of dying out or, as a result of drastic changes in conditions and climate, survive in what amounts to only a fraction of their former range.
\end{abstract}

Apart from their individual interest, these relicts are a potential source of information as to former climates and conditions. One knows that these widely separated elements must at one time have been distributionally connected, or at least have lain much closer together. Each plant or animal species has its own conditions for survival: postulated distributional connections carry with them the proof that what is now desert must formerly have been fertile or, in some instances, the reverse. Lastly, relics may be intrinsically interesting in the study of evolution and speciation. Despite the small size of the populations involved they are often differentiating, or have differentiated, into new species.

Australia is an arid continent. But for much of the Tertiary and Pleistocene geological periods, the latter extending back to a million years ago, it was a relatively fertile one. Ten thousand to fifty thousand years ago (the actual period is somewhat uncertain) it became arid. The reasons for this are ill-understood. It has remained arid ever since.

\section{Australia's Former Fertility}

Evidence for the former fertility of the Australian continent comes mainly from three sources:

(a) Dry salt lakes occur over extensive areas of the interior, and the beds of dry rivers ramify widely through the central sections of the desert. Many of these never hold water today, or else do so only for parts of their course at times of exceptional flood. Borings have shown that, underlying these water-systems, may be hundreds of feet of silt and sand, the residue of countless thousand of years of good flow. Pleistocene deposits are, for example, $400 \mathrm{ft}$. deep in Lake Frome, South Australia. The Murray and Darling, our "great rivers" of today, are now actually only senile streams. They, too are characterized by alluvium that may be hundreds of feet thick in places. This sum of geological evidence, plus that from other sources, has led the geologist Dr. W. R. Browne to describe the Pleistocene period in Australia as "a time of high rainfall and the continent, even in its central parts ... a land of brimming rivers, spreading swamps, and full-bosomed lakes".

(b) Fossil remains of giant herbivorous animals, much larger than, and quite unlike, any today, are abundant in lake and river deposits, including those of the desert. Included in these are those of Diprotodon, a huge wombat-like animal with the bulk of a rhinoceros; Nototherium, a slightly smaller grazer of the same general type, and Palorchestes, an extinct kangaroo $10 \mathrm{ft}$. high. Such creatures could only have lived under conditions of lush vegetation and abundant water. In addition to these, crocodile and lungfish fossils have been found in South Australia, hundreds of miles to the south of their range today.

(c) Relict pockets of living "high rainfall zone" plants and animals occur in remote parts of the desert.

It is my objective, in this article, to bring together some recent findings, with respect to $(c)$, in an interesting sector, the Macdonnell Ranges of central Australia.

Perhaps the most publicised case of a relict distribution in Australia is that of the grove of palms, Livistona mariae, along a tributary of the Finke River. Since their discovery by the explorer Ernest Giles in 1872 repeated generations of naturalists and geologists have discussed and speculated 

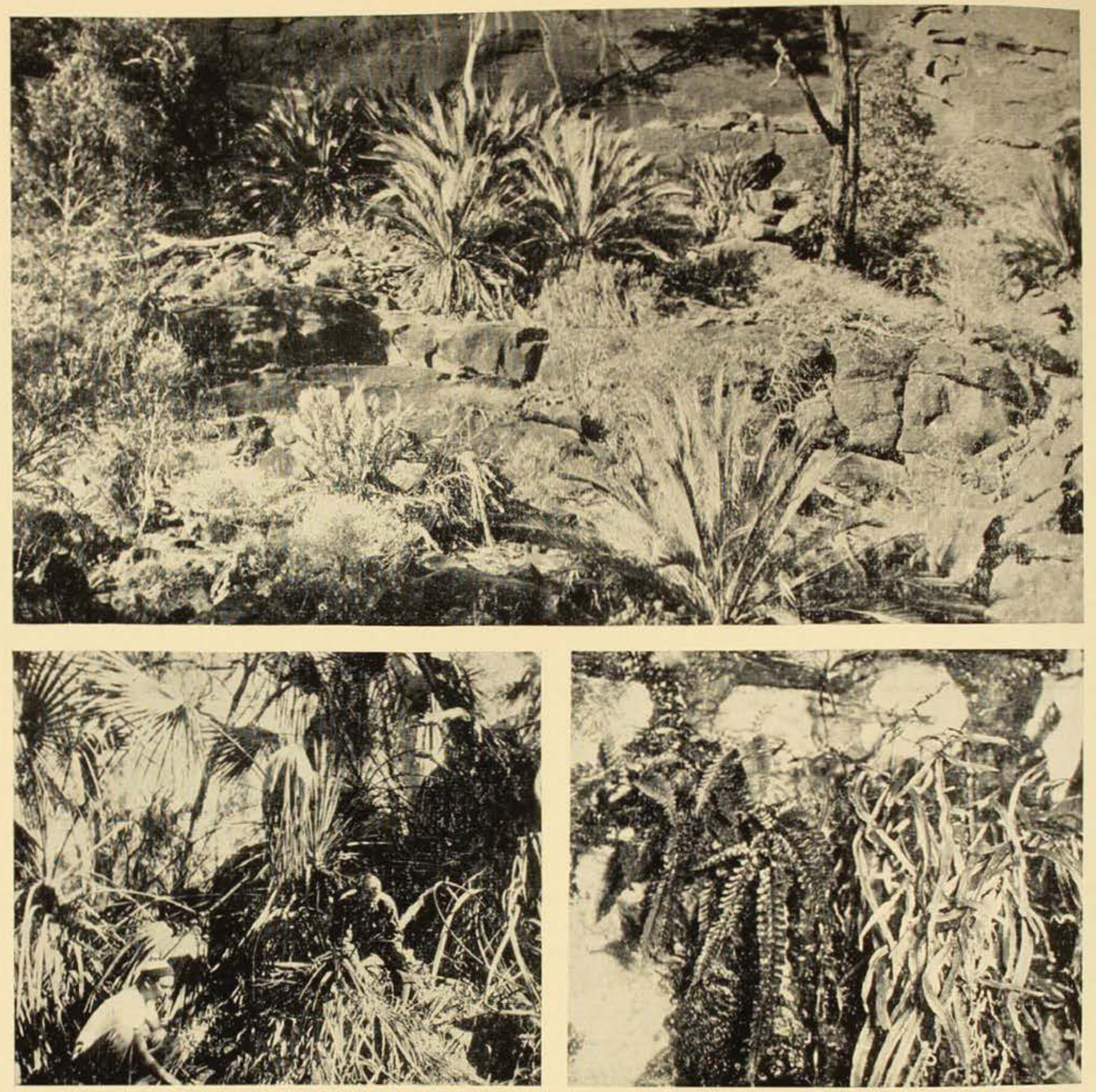

In the Macdonnell Ranges.-(Upper): Cycads (Macrozamia) and (Lower left) young palms (Livistona) in Palm Valley. Lower right: The ferns Adiantum hispidulum and Lind. saea ensifolia in Talla Putta Gorge.

Photos, by the Author

Left: Distribution (in black)

of Macrozamia, a
genus, which has
many species in the many species in the

The genus Livistona (cabbage-tree palms) has several species in Arnhem

Land. Note many relict species in other places. The cycads are of south-western, and the palms apparently of northern, origin.

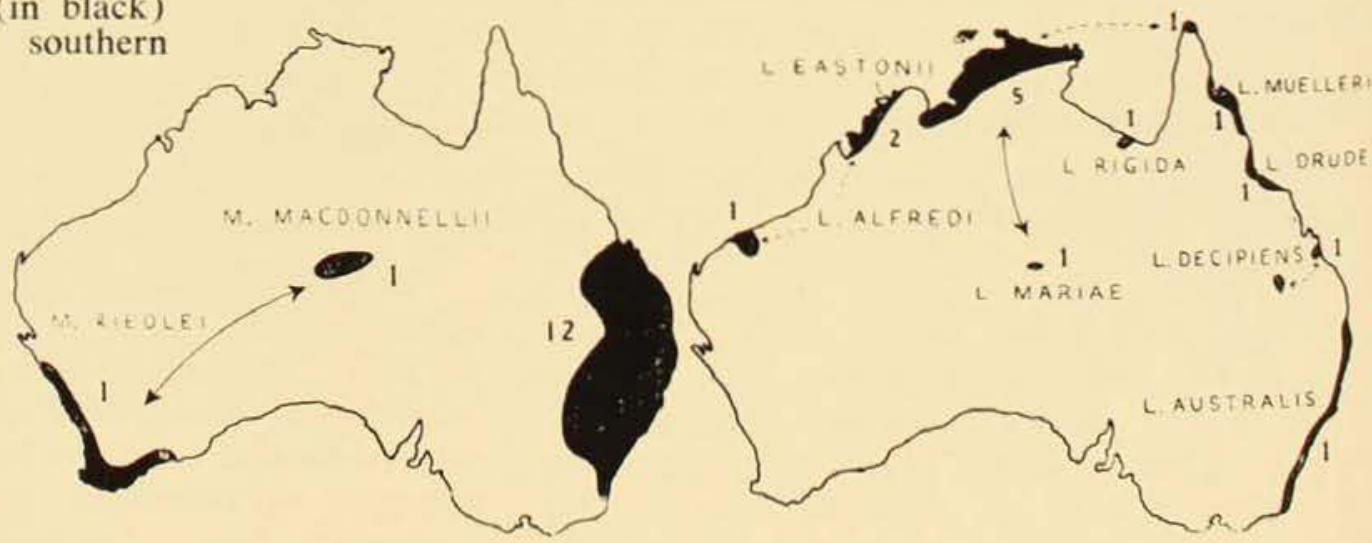

Maps by Wendy Manwaring: information by L. A. S. Johnson and S. T. Blake. 
about this stand, for there are no other palm trees closer than coastal New South WalesQueensland and along the seaboard of the Northern Territory, 1,100 and 700 miles to the east and north, respectively. The stand's persistence in this restricted area is surprising enough (a rough count by the writer in September, 1958, disclosed a total of about 300 individuals at all stages of growth). It is nothing, however, compared to the inference that must be drawn therefrom - that palms formerly extended right down, or across, the continent.

Another well-known case of relict survival is that of the cycads in the Macdonnell and George Gill Ranges. Here the endemic species (Macrozamia macdonnellii) is the relict of a genus that occurs elsewhere only in coastal south-western and south-eastern Australia.

Once the fact that these relicts indicated former generalized fertility in the Australian interior became established further interest in the Macdonnell Ranges as a relict area temporarily died down.

\section{Exciting Discovery}

Then, in 1953, came an exciting discovery by way of a Lutheran missionary, E. Rieschieck. Two species of moss (the cosmopolitan Fissidens asplenioides and the circum-Antarctic Philonotis tenuis) and three species of ferns (Adiantum hispidulum, a maiden-hair, Histiopteris incisa and Nephrolepis cordifolia) were received by $\mathrm{Mr}$. J. $\mathrm{H}$. Willis, of the National Herbarium of Victoria. They came from Talla Putta (TalliPatta), a newly-discovered gorge at the western end of the Macdonnell Ranges, 35 miles west of Haast Bluff. Rieschieck had been conducted to the gorge by a group of Pintubi tribesmen that had only recently come into settlement for the first time. Talla Putta was of considerable importance to these people as it had two pools of permanent water in otherwise dry country, one at its entrance and the other at its far end.

The relict mosses and ferns (there are apparently actually five fern species in the gorge, the names Lindsaea ensifolia and Cheilanthes tenuifolia having also been given the writer by Northern Territory Administration botanist G. Chippendale) created renewed interest among people interested in relict biogeography. Admittedly, these two plant groups have a form of dispersal (spores) that favours wide distribution, and so they are not quite such telling evidence of generalized fertility. However, they certainly add important corroborative information.

The writer first learned of Talla Putta in 1956 from Mr. Norman Tindale, ethnologist to the South Australian Museum, who had recently visited the area. The writer determined to make a further visit to the Macdonnells with the special objective of seeking out animal relicts and determining their relationships. In Sydney, Dr. D. F. McMichael, of the Australian Museum staff, also became enthusiastic, and together we made a search of central Australian literature for possible information.

The report of the famous Horn Expedition (1894), that did so much to discover and reveal fundamental information on desert species, brought two most interesting cases to light. Among these was a newly-discovered species of earthworm, Acanthodrilus eremius, found in a few areas of moist soil in the Macdonnells. The genus only occurs in coastal northern and southwest Australia (J. Stephenson). Amongst the dozen land-snail species was found one belonging to the south-western genus Bothriembryon. Later research has proved that, outside of the south-west corner (where there are thirty-three named forms), there are a single species of Bothriembryon on the Nullabor Plain and a couple on Eyre Peninsula, in addition to the Macdonnells species.

\section{Extensive Collections Made}

During our visit (September, 1958) Dr. McMichael and the writer were guests of the Northern Territory Administration and of its biologist, Mr. Alan Newsome. We had the good fortune to be taken by Land Rover over a large section of the western Macdonnells. The tract covered extended to a point some 50 miles west of Haasts Bluff. A special search was made near waterholes, it being considered that in their vicinity was the most likely place to discover relict elements. Those visited included ones on the Hugh River, upper Ellery Creek, Ormiston Gorge, Glen Helen, Talla Putta and Palm Creek, as well as several minor sand-holes and mud-holes. 

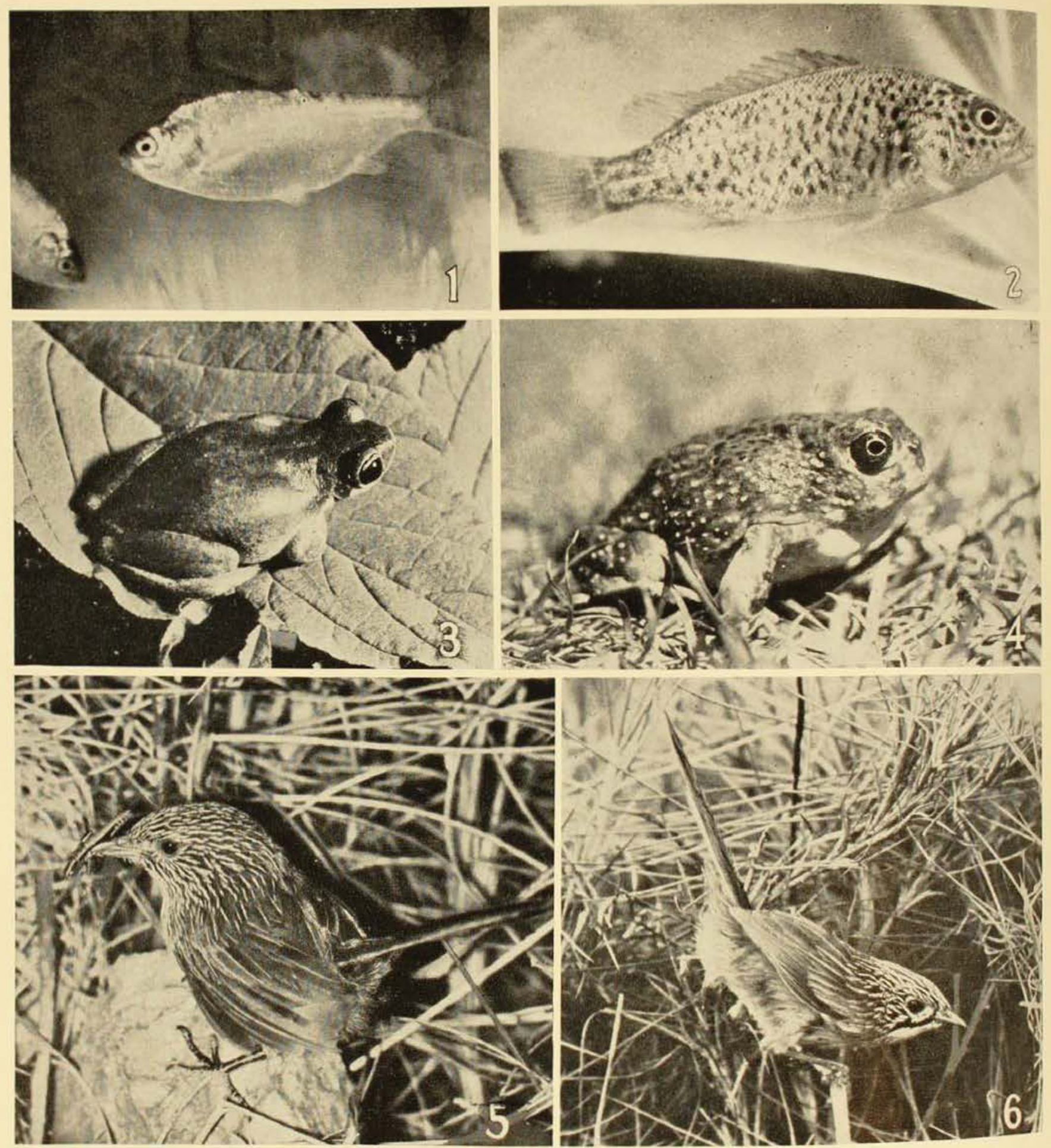

Some central Australian animals, origins arid habitats: (1) Hair-backed herrings (Fluvialosa richardsoni), stream fish: near relatives in Murray-Darling: in central Australia confined to permanent rock-holes in mountains; apparently unable to aestivate in mud. (2) Spangled grunter (Madigania unicolor). In ponds and sluggish streams of northern two-thirds of Australia: aestivates in dried mud. (3) Tree frog ( Hyla rubella). Almost Australia-wide. but in central Australia confined to mountains: cannot burrow or aestivate underground (4) Burrowing frog (Notadon nicollsi). Confined to ephemeral watercourses of sandplains: aestivates underground; this specimen was dug from dry bed of Lander River; near relative in western N.S.W. (5) Western grass-wren (Amytornis textilis). In central Australia restricted to rock walls of mountain gorges: apparently of western origin. (6) Striated grass-wren ( $A$. striatus); wide range; confined to spinifex sand-plain; avoids mountains.

Photos by E. McNamara, H. G. Cogger and the Author 
In these areas extensive collections of invertebrate life were made. At the vertebrate level, in which it was considered unlikely that many "old" relicts would be found, the work concentrated on a study of the differences between the species inhabiting the mountains and those of the surrounding sand-plains (the Australian Museum had already collected widely over central Australia in 1937 and 1952). The results are yet to be fully assessed. Some of the main findings can, however, be stated, but before listing these I would like to give a brief account of the fern glen at Talla Putta, the sight of which provided easily the most exciting moments of the trip.

Up to our arrival at Mount Crawford, in which Talla Putta lies, we had journeyed through hundreds of miles of country so completely parched and dry that one could not have believed that ferns occurred within hundreds of miles. The gorge itself is, in effect, a narrow chasm, hot and parched because of the sunlight reflecting from the rugged red walls. In its twistings and turnings one has to struggle over and around boulders and scramble through fallen trees and dry brush.

The head of a left-hand fork ends in a blind cul-de-sac surrounded by high cliffs on three sides. Here, where the sunlight rarely reaches and dense shrubs shut out the sky, there is a small pool, and a deep fissure extends back into the rock. The rock glistens with water, and a small spring trickles down. The whole of the walls are festooned with ferns - a long-dropping, hard-leaved species, short-leaved pinnate ones that stick out vertically from the rock, and soft, delicate maiden-hairs. Moss grows profusely. We felt that we could have been in a sheltered creek in the Dandenongs or in Sydney's Royal National Park. That such a luxuriant ferny nook could exist in arid central Australia seemed almost beyond realization.

\section{Scientists' Findings}

Initial findings on some of the animal groups are as follows:-

Dragonflies: Of the three species collected, one, the large blue Orthetrum caledonicum, is an inhabitant of New South Wales and Queensland. Dragonflies are, however, great wanderers.
Fresh-water Snails: Several species were collected, most of which belonged to widespread groups. However, one small caplimpet proved of particular interest, as it belongs to a genus and species (Stimulator consetti) previously known only from a single locality in the Harding Ranges of north-western Australia. (D. F. McMichael.)

Land Snails: A dozen or more species were collected by the Horn Expedition, and most of these were found again. Some live among the fallen leaves of the Desert Fig (Ficus platypoda), a "northern" plant with a wide desert range. Others were found hidden away under the fallen palm fronds in Palm Valley and under the fallen leaves and twigs of a shrubby Melaleuca. Nearly all these species are confined to the interior mountain ranges, and belong to widespread desert-adapted groups.

Bothriembryon, of which only a single colony was found by the Horn Expedition, unfortunately could not be located, despite intensive searching. (D. F. McMichael.)

Butterflies: All the five species found were ones that normally extend out into the dryer country, though it was obvious that the Macdonnells were a centre of abundance and that these butterflies were rare outside them.

Earthworms: Individuals of one species were found (Talla Putta Gorge). It is presumably Acanthodrilus eremius, but this has yet to be ascertained.

Fresh-water Fishes: Of the five species collected all are northern Australian except one, Fluvialosa richardsoni (endemic race horni), the relatives of which live in the Murray-Darling system. (G. P. Whitley.)

Reptiles, mammals, frogs and birds: It is readily apparent that the ranges have a slightly different fauna from that of the surrounding sand-plain, as well as a much richer one. In frogs and reptiles there is evidence of colonization of central Australia both from the north and south. The Macdonnells have a distinct endemic species of pouched mouse (Pseudantechinus macdonnellensis), a distinctive blind snake (Typhlops endoterus) and a few endemic races of birds. There is no doubt that, in all these vertebrate groups, various isolated 
populations occur in the Macdonnells. The distance of separation from their near relatives outside, however, tends to be much less than is the case in invertebrates and plants.

\section{Central Australian Flora}

Mr. George Chippendale, Northern Territory Administration botanist, is preparing, after extensive field work, a comprehensive flora of Central Australia. An increasing number of real plant relicts is now being found by Mr. Chippendale, Mr. L. A. S. Johnson, of the National Herbarium, Sydney, and others. The names of some of these have been supplied. They include an endemic flannel flower (Actinotus schwarzii), a rush (Juncus) and a teatree (Melaleuca linariifolia), all of whose affinities lie with species living in coastal eastern Australia. In addition, the cycads of the Macdonnells have recently been restudied by $\mathrm{Mr}$. Johnson, and the palms by $\mathrm{Dr}$. S. T. Blake, of the Botanic Museum, Brisbane.

The distribution of Macrozamia and Livistona, and the relationships of the Macdonnell species to those beyond, are shown in the two maps. They contrast in that the cycads are most closely related to $\mathrm{Mac}$ rozamia riedlei, of coastal south-western Australia, and the palms apparently to those of northern Australia.

It is apparent from the initial handful of instances quoted here that the relict plants and animals of the Macdonnells are not derived from a single-point source but have had a multiple origin, some coming from the north, others from the south-east, and still others from the south-west. They provide what now could only be called an abundance of "living evidence" of Australia's former fertility. Again, it has long been postulated, on the grounds of known facts about shifting wind (and hence rainfall) belts, that even during the fertile Pleistocene the continent was never uniformly fertile at one time but was subject to a complicated series of climatic fluctuations, though it was never as arid as it is today. At one time the southern, and at another the northern, half was fertile. There was a series of south-north "oscillations" of rainfall belts, with the high rainfall zone of the south coast swinging northwards and carry. ing the desert before it. On other occasions the high-rainfall zone of the north migrated southwards. The new work in the Macdon. nells provides biological support for this. Obviously, at one time the northern, on other occasions the southern (eastern), or southern (western), species colonized and left behind relicts in the Macdonnells.

\section{New Cave-dwelling Shrimps Found}

The Australian Museum has ac. quired from the Milyering district of N.W. Cape, Western Australia, some small freshwater shrimps of great interest to zoologists.

The specimens were collected by Mr. A. Snell, of Bunbury, West Australia, in the dark recesses of a well, bored down through coral and limestone country. They lack sight and have been identified as true troglobic (cave-dwelling) forms - the first to be recognised from the Australian continent, and new to science.

The task of providing the shrimps with a scientific name and preparing a description of them for publication in the Records of the Australian Museum is being undertaken by Dr. Lipke Holthuis, of the Leiden Museum, Holland. Dr. Holthuis is a world authority on the prawn and shrimp groups of the crustacean class.

\section{Protection of Aboriginal Relics}

The Cumberland County Council. which administers the planning of the county in which Sydney is situated, is examining aboriginal relics in its area with a view to proclaiming many of them as reserves, for their protection. The relics include rock engravings, paintings and stone arrangements. This is the most constructive step yet taken in any Australian local-government area to protect aboriginal relics. 


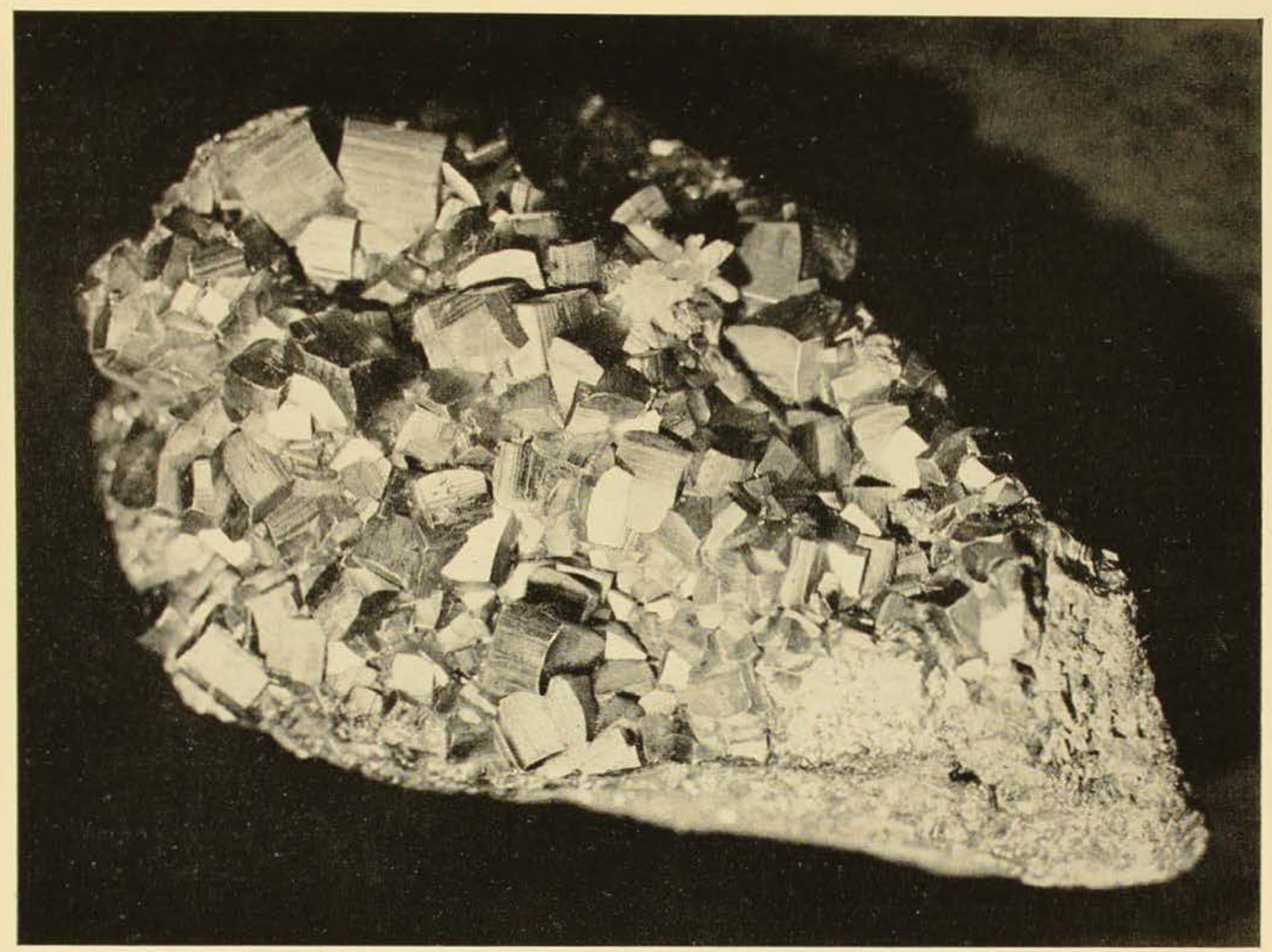

A fine specimen of pyrite crystals from Leadville, New South Wales.

Photo-- Howard Hughes.

\section{Fire and Brimstone}

By R. O. CHALMERS

EVERY school-boy collector knows iron minerals.

Its correct name is pyrite, and it is a sulphide of iron. It is a distinctive mineral because it frequently occurs in the form of cubes and has a characteristic brassy yellow colour and a metallic lustre. It is rather contemptuously referred to as "new chum's gold" or "fool's gold" because its superficial resemblance to the precious metal confused and misled the "new chum" prospector.

Primitive man of all races valued this common mineral because he knew that when struck with some hard object, such as a lump of flint, it gave off sparks. Hence, it was used in fire making. The little sparks are actually tiny particles of the mineral made incandescent by the impact of the flint. The very word pyrite is derived from the Greek word for "fire". A sulphurous smell is noted, too, because the heat of impact is sufficient to cause each tiny particle to burn in the atmosphere, forming the gas sulphur dioxide.

Let us bring this early prehistoric scene on to the stage of modern times. It is changed beyond recognition by the complexities of present-day technology. Tons of finely-ground pyrite, which must also be 
perfectly dry, are fed into specially designed furnaces and heated by the sudden application of a temperature sufficiently high to cause ignition and the evolution of the gas sulphur dioxide. This is known as "flash roasting", and is the first stage in the manufacture of sulphuric acid, the most important single commodity in the chemical industry.

\section{Sulphur-burning Method}

An easier method of making sulphur dioxide is by burning the familiar naturallyoccurring bright yellow sulphur. The common name, brimstone, for sulphur is derived from the old English word "to burn". To produce a given amount of sulphuric acid the amount of sulphur used need only be half that of pyrite. Sulphur burns at a lower temperature than pyrite. It is almost entirely consumed in the burning process, whereas iron oxide remains after pyrite and care must be taken that no trace of sulphur remains if it is to be used as a source of metallic iron.

The extraction of sulphur from its source, by forcing superheated water into deepseated beds and pumping molten sulphur to the surface, is cheaper than mining pyrite, crushing it, most likely having to separate it from associated minerals, and finally concentrating it. However, sulphur in its native form is not an over-abundant mineral in the earth's crust and, in terms of sulphur content, about as much pyrite is used the world over as is native sulphur. The great industrial importance of sulphuric acid is illustrated by the well-known statement
"A nation's consumption of sulphur is a measure of its industrial progress".

Sulphuric acid is not only a vital chemical in highly industrialized countries, but is of equal importance to a country with an economy based on agriculture. Superphos. phate fertilizer is made by treating phos. phate minerals with sulphuric acid, and most by far of this acid made in Australia is used for this purpose. U.S.A. is the world's chief source of sulphur. In the last 10 years Australia's financial problem in having to purchase from a dollar area, together with shortages due to American stockpiling in the period of the Korean War, led our country to increase its production of pyrite. In some of Australia's large mines, such as Mount Lyell, Mount Morgan, Captain's Flat and Kalgoorlie Gold Mines, pyrite is associated in quantity with the principal mineral mined, and concentrates are produced as a by-product. (For further details of pyrite at Mt. Lyell see this magazine, XI, 7, 1954, 229-231.)

Production from these sources was in. creased and a most unusual step taken-that of working certain deposits for pyrite and nothing else. At the Iron King Mine, Norseman, Western Australia, for some years, py. rite has been mined directly from a lode that is quite separate from the gold lodes At Koolyanobbing, 220 miles east of Perth. there is an important pyrite deposit as yet untouched.

The biggest production of pyrite in Aus. tralia is at Nairne, some 25 miles south-east of Adelaide. There, two beds of somewhat

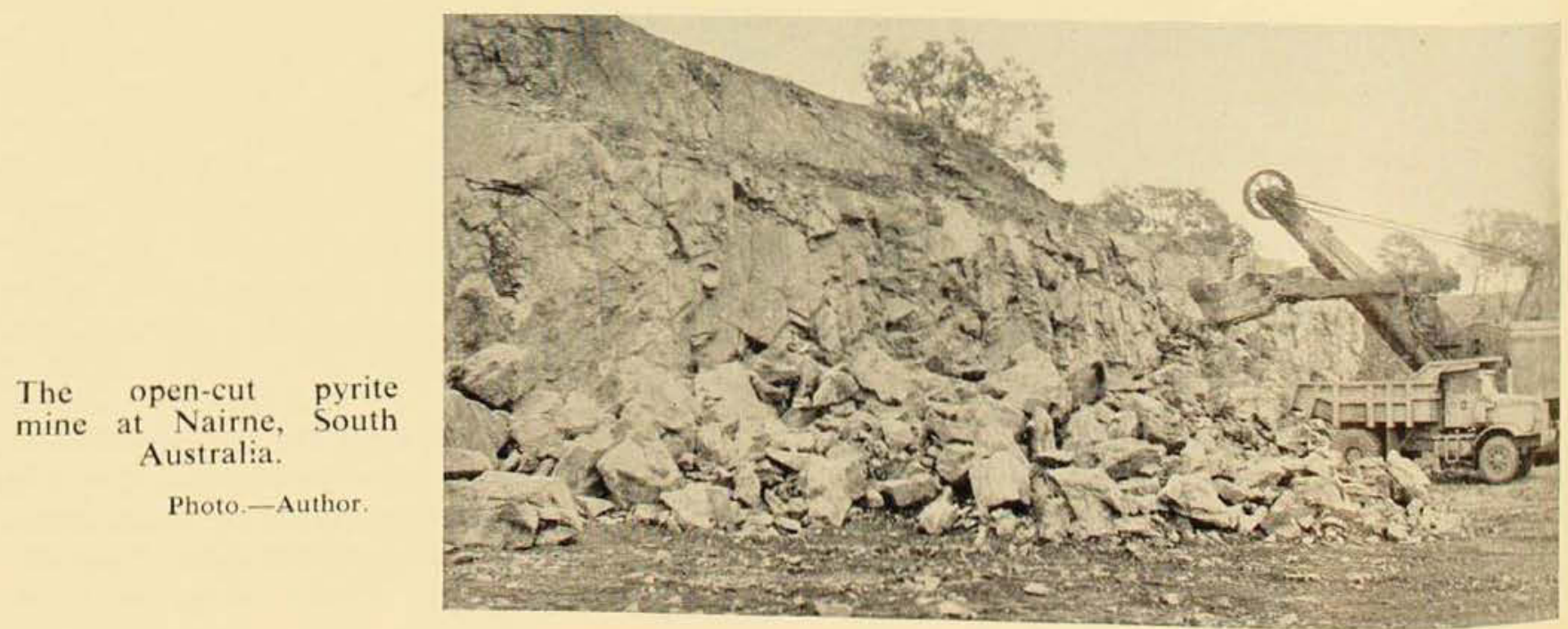


metamorphosed feldspar bearing sandstones and shales, one $50 \mathrm{ft}$. and the other $100 \mathrm{ft}$. thick, contain pyrite and pyrrhotite (a related iron sulphide) to a maximum of 15 per cent. of the rock by volume. The pyrite is considered to have been formed at the time these sediments were being laid down under marine conditions. In the absence of fossil evidence the exact age of the host rocks is unknown, but they are considered to be of Upper Cambrian age (some 450 million years old). These pyrite-bearing formations outcrop over a distance of 65 miles. With the sponsorship and help of the South Australian Government, mining by open-cut methods began in 1955. The pyrite-bearing rock is crushed, and the pyrite is separated from the rock and concentrated. It is then railed to one of the largest sulphuric acid plants in the Southern hemisphere, at Birkenhead, near Port Adelaide. From there, acid goes to South Australia's six superphosphate plants.

Although not quite relevant to this article, it should be noted, for the sake of completeness, that there are sulphuric acid plants at Risdon, Tasmania, and Port Pirie, South Australia, that use sulphur dioxide produced in the smelting of Broken Hill zinc and lead concentrates.

\section{Pyrite-mining Progress}

It should be made clear that elemental sulphur has by no means been entirely supplanted in Australia, but the following figures show the development of the pyritemining industry in recent years. In 1950, of the 650,000 tons of sulphuric acid produced in Australia, 17 per cent. came from Australian pyrite. In 1957, nearly $1,000,000$ tons of acid was produced and a little over half came from indigenous raw materials. Of this total, 31.5 per cent. was manufactured with the use of Australian pyrite as raw material.

Finally, from the Museum specimen point of view, the great attractiveness of this rather common but vastly important mineral should not be forgotten. A long disused silver-lead-zinc mine at Leadville, near Dunedoo, New South Wales, used to produce superb groups of pyrite crystals which enhance the appearance of display collections in this and other Museums throughout the world.

\section{Notes and News}

\section{Award of Clarke Medal}

The Royal Society of New South Wales has awarded the Clarke Medal for 1959 to $\mathrm{Mr}$. Tom Iredale for distinguished contributions in the field of zoology. Mr. Iredale was conchologist at the Australian Museum for 20 years and, since his retirement in 1944, has been an honorary zoologist there, specialising in birds as well as molluscs, about both of which he has written many books and scientific papers. The medal commemorates Rev. W. B. Clarke, "father of Australian geology", who was connected with the Australian Museum in various capacities from 1838 to 1894. In the past 70 years five members of the Australian Museum staff have been awarded the Clarke Medal, the highest honour the Reyal Society of New South Wales bestows.

\section{Dr. A. Spoehr's Visit}

Dr. A. Spoehr, Director of the Bernice Pauahi Bishop Museum, Honolulu, visited the Australian Museum on his way back from Micronesia, where he carried out field work in archaeology.

\section{Meteor Near Sydney}

Information has been received from $\mathrm{Mr}$. E. C. B. MacLaurin, Lecturer in Semitic Studies at the University of Sydney, to the effect that at 4.30 p.m. on Saturday, May 30 last, a meteor passed overhead, not much above tree-top level, two miles south of St. Mary's. It was incandescent, and burned with a very green flame. It vanished suddenly in a puff of white smoke, having burned itself out completely. A strong metallic smell, such as one smells during welding, was noted. So close was it that, had it been large enough to strike the earth before being consumed, the noise of impact would have been noted by a nearby observer. Such observations are rare in a sparsely populated country like Australia. Of the 100 known Australian meteorites only eight have been seen to strike the earth. There are no statistics on the frequency of the phenomenon of meteors burning out close to the earth. A vital factor would be the density of population in the country concerned. Generally, it would be reported infrequently in Australiaperhaps only once every two or three years. 


\section{THESE SHELLFISH ARE GOOD TO EAT}

\section{By DONALD F. McMICHAEL}

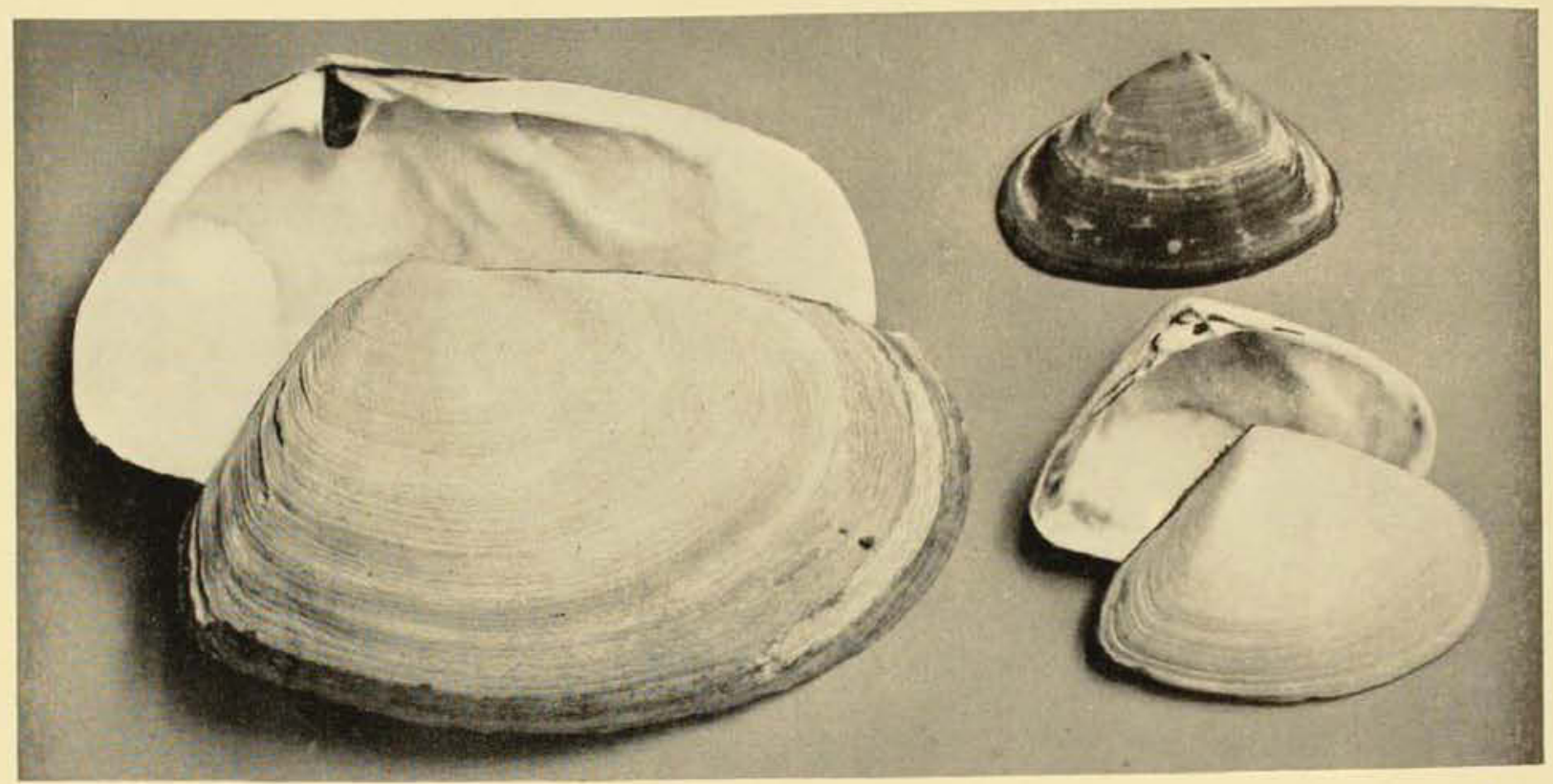

Left: The famous New Zealand Toheroa (Amphidesma ventricosum). Right: Pipis (Plebidonax deltoides), which are sold as food in New South Wales. The top shell is young and still has its characteristic greenish periostracum (outer horny layer).

\section{Photo--Howard Hughes.}

"Tom, whom today no noise stirs,

Lies buried in these cloisters;

If at the last trump,

He does not quickly jump,

Only cry, 'Oysters'."

Tom, a Colchester man, whose epitaph appears above, obviously appreciated the delicacy of the oyster.

Millions of other people throughout history have likewise regarded the oyster as a valued food, yet it is only one of a whole family of gastronomic delights which are members of the phylum Mollusca - the true shellfish. Other animals which pass under the name "shellfish" are crustaceans, like the lobster, the crab and the prawn, but of course neither they nor the molluscs are really fish.

Among the better-known molluscan species used as food in European communities are mussels; clams of various kinds, such as the Australian Pipi, the New Zealand Toheroa and the American Quahog or Hard-shell clam; scallops ; squid and octopus; winkles: abalones or mutton fish, and the land snails so favoured by the French. These, however, are only the common food species of European communities; a thousand others are eaten by non-Europeans, especially the native people of the Pacific Islands.

\section{Oysters And Pipis}

The Sydney Rock Oyster (Crassostrea commercialis) belongs to the genus which provides most of the world's delectable oysters, including the famous eastern American Virginia Oyster. The Sydney oyster is as flavoursome as any, however. It is consumed in large quantities, about eight to ten million pounds in the shell being produced annually in New South Wales. In Queensland and Western Australia other species of Crassostrea are harvested.

In South Australia and Victoria the Port Lincoln or mud oyster is still marketed. This species, Ostrea sinuata, is the same as that found at Stewart Island, off the 
southern tip of New Zealand, and is one of the famous oyster delicacies of the world. The shells grow quite large - as big as a saucer, commonly. These oysters must have been quite abundant along the coast of New South Wales in the past, for they occur frequently in Aboriginal kitchen middens. They are rarely found now, however, though occasional specimens are dredged up from the deeper parts of Port Hacking and Botany Bay.

In post-war years the Pipi (Plebidonax deltoides) has become the basis of a New South Wales industry. The pipis are sold canned, in a minced form, as soup-stock, and whole as "butter clams". At first they were fished on south coast beaches by large, tractor-drawn potato-diggers, which were dragged through the sand between tidemarks at low tide; the adult pipis were raked out, but the young were allowed to remain. However, demand was not sufficient to maintain such a high rate of fishing, and the pipis are now hand-collected from a number of north coast beaches. This species was also much favoured by the Aborigines as food.

Another kind of bivalve mollusc eaten commonly in Europe, but little as yet in Australia, is the mussel. Bottled mussels have been available for years in Melbourne. and recently these, as well as canned Danish mussels, have appeared in Sydney shops. A few Sydney restaurants serve fresh mussels (Mytilus planulatus), obtained from unpolluted waters near the city, but as yet the species is little used. Enormous numbers of mussels are found on wharf piles, but great care should be taken that they are not growing in polluted waters if they are to be used as food. Any nearby shipping, drainage or sewage outlets are potential sources of infection.

\section{Big Scallop Hauls}

An edible mollusc with a difference is the scallop. The word "scallop" has been used in several ways in Australia, but the true scallop is one of several species of the family Pectinidae. The main Australian scallop-fishing centres are Tasmania, Queensland and Western Australia.

In Tasmania three different species are fished commercially - the Queen Scallop (Equichlamys bifrons), the Doughboy Scallop (Mimachlamys asperrimus) and the Commercial Scallop (Notovola meridionalis). Of these, the latter makes up by far the bulk of the catch of some $4,500,000$ pounds a year, taken during the three months (May-July) fishing season. Most of the Tasmanian fishing is done in the d'Entrecasteaux Channel, where the scallops are caught in dredges towed along just above the bottom. The molluscs are extremely active, have good eyesight and can detect the shadow of the approaching dredge. They jump out of the way speedily when dredging commences, but after a while tire from their efforts and are easier to catch. Fishermen refer to this as "getting the scallops working". Only the large adductor muscle of the animal, together with its foot, which is usually coloured a bright orange, are eaten.
The Port Lincoln or mud oyster (Ostrea sinuata), of Victoria. South Australia and Stewart Island, New Zealand, is one of the world's noted oyster delicacies. This species is occasionally found on the New South Wales coast. The specimen in the photo. came from Sydney Harbour

Photo.-Howard Hughes.

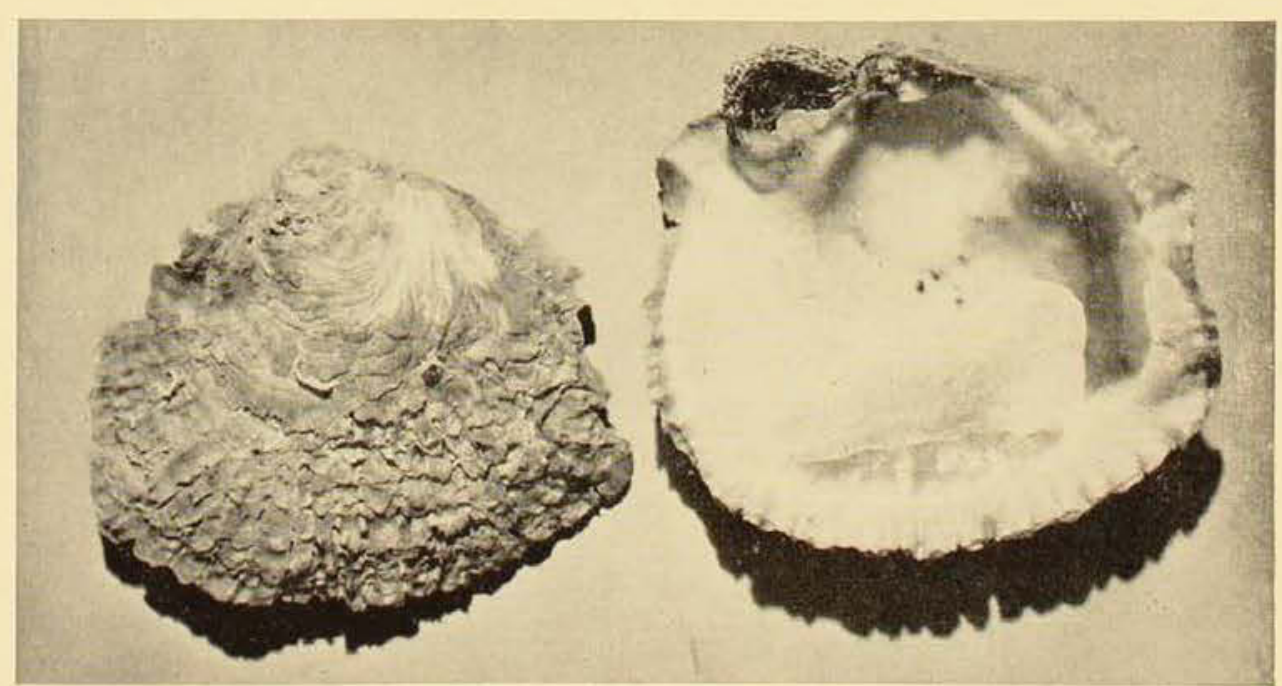


In Queensland and Western Australia a different kind of scallop. Amusium balloti, is fished. It has a large, very smooth, saucerlike shell. The industry has not yet become stabilised in these States, however.

Before finishing with the bivalve molluscs, mention should be made of the famous New Zealand Toheroa (Amphidesma ventricosum). This delicacy formerly occurred in vast numbers on the ironsand beaches of New Zealand, but over many years, and through various causes, its numbers have been drastically reduced. A strict control now operates on the taking of this species. It can only be taken over a short open season, and there is a limit on the numbers which can be gathered by any one digger. Toheroa are very quick and active, and live between tide-marks about six inches under the sand surface.

\section{Australian Abalones}

Inquiries are frequently made as to the possibility of eating local mutton-fish or abalone. A number of people have proposed to fish abalone commercially in Aus. tralia, and recently significant numbers have been taken in Tasmania. Some 1,600 lb. liveweight were fished there during 1957-58. However, the common eastern Australian species, Notohaliotis ruber. is probably neither large nor common enough to warrant a full-scale commercial fishery.

In the western United States and Canada, the abalone fishery is of some importance. The Californian fishery depends mainly on the Red Abalone (Haliotis rufescens), which reaches about $12 \mathrm{in}$. in length. The minimum legal size for taking this species is 7 in., and fishermen are restricted to a catch of five per man per day. Other species are fished in smaller numbers and are controlled by minimum legal sizes. The foot of the abalone is eaten after tenderising with a mallet, but is very tough unless thoroughly beaten or sliced very thin.

The Australian abalones are all rather small in comparison, the two largest being the common Notohaliotis ruber, and the Southern White Ear-shell (Schismotis albicans), both of which reach about 6 in. in length. Local skin-divers have lately collected enough abalones for home consumption. The species is commonest below low-

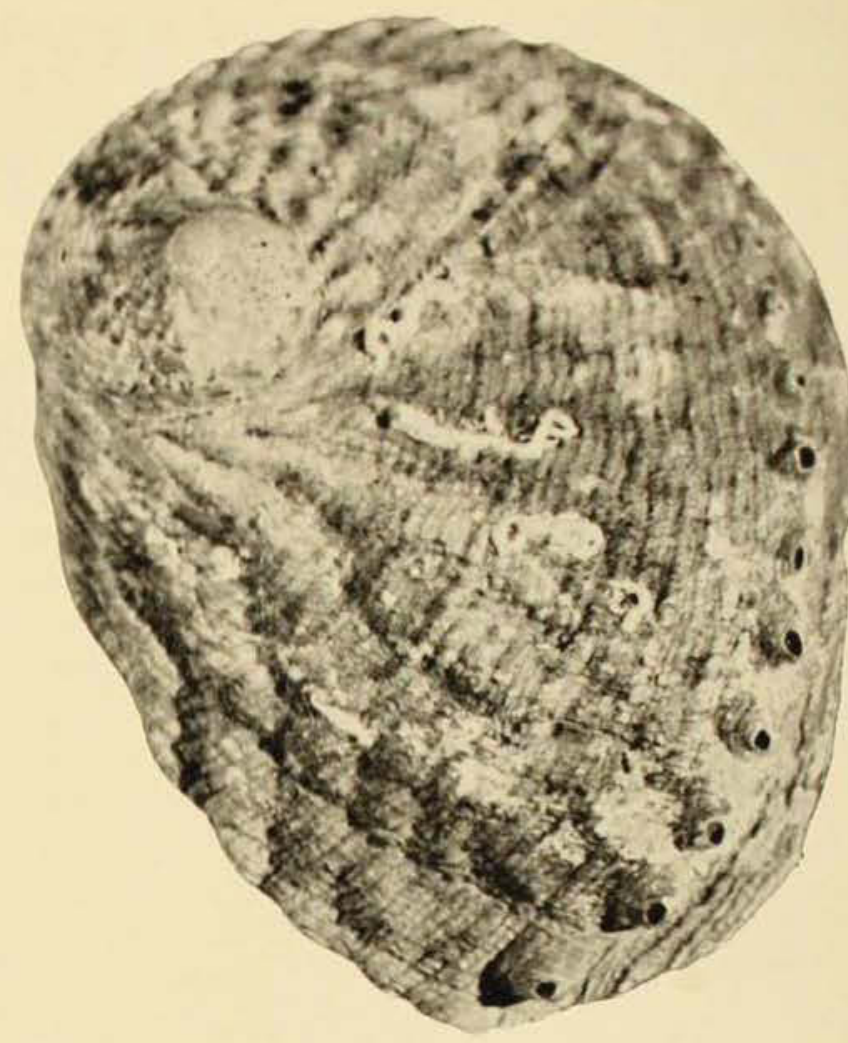

Small quantities of abalone, or mutton-fish, are used as food in Australia. Above is the common eastern Australian abalone (Notohaliotis ruber), which reaches a length of about 6 ins.

Photo--Howard Hughes.

water mark, though fair numbers can be found between tidemarks, on rock platforms, in crevices and under stones.

Apart from the abalone, gastropods are not commonly eaten in Australia. Winkles, so beloved by the English, are not sold commercially here, though this type of shellfish occurs in abundance on the rock platforms around Australia. The meat of the trochus shell is considered a delicacy by the Chinese, and was once gathered in quantity in Australia, dried, smoked and exported to China

\section{Squid As A Food}

The only other class of molluses eaten commonly are the cephalopods - squids, cuttlefish and octopus. Recently squid have been marketed in fair commercial quantities in Australia, the total for 1957-58 reaching over $134,000 \mathrm{lb}$, and small quantities of octopus are on sale.

The Japanese squid fishery is really large. however, some 500,000 tons being caught annually. This was one-fifth of the total 
Japanese marine production for 1952. The Japanese squid catch is used most economically; some of it is canned, some is dried, oil is extracted from the viscera, and the remnants are reduced for chicken food.

In Australia, squid are mainly netted, but in the Mediterranean they have been caught in the same way for several thousand years - in baited conical traps woven from fine rushes which are linked at intervals along a cable. These are laid parallel to the shore and raised daily. Some Mediterranean fishermen use a captive female squid, tied to a line and allowed to swim

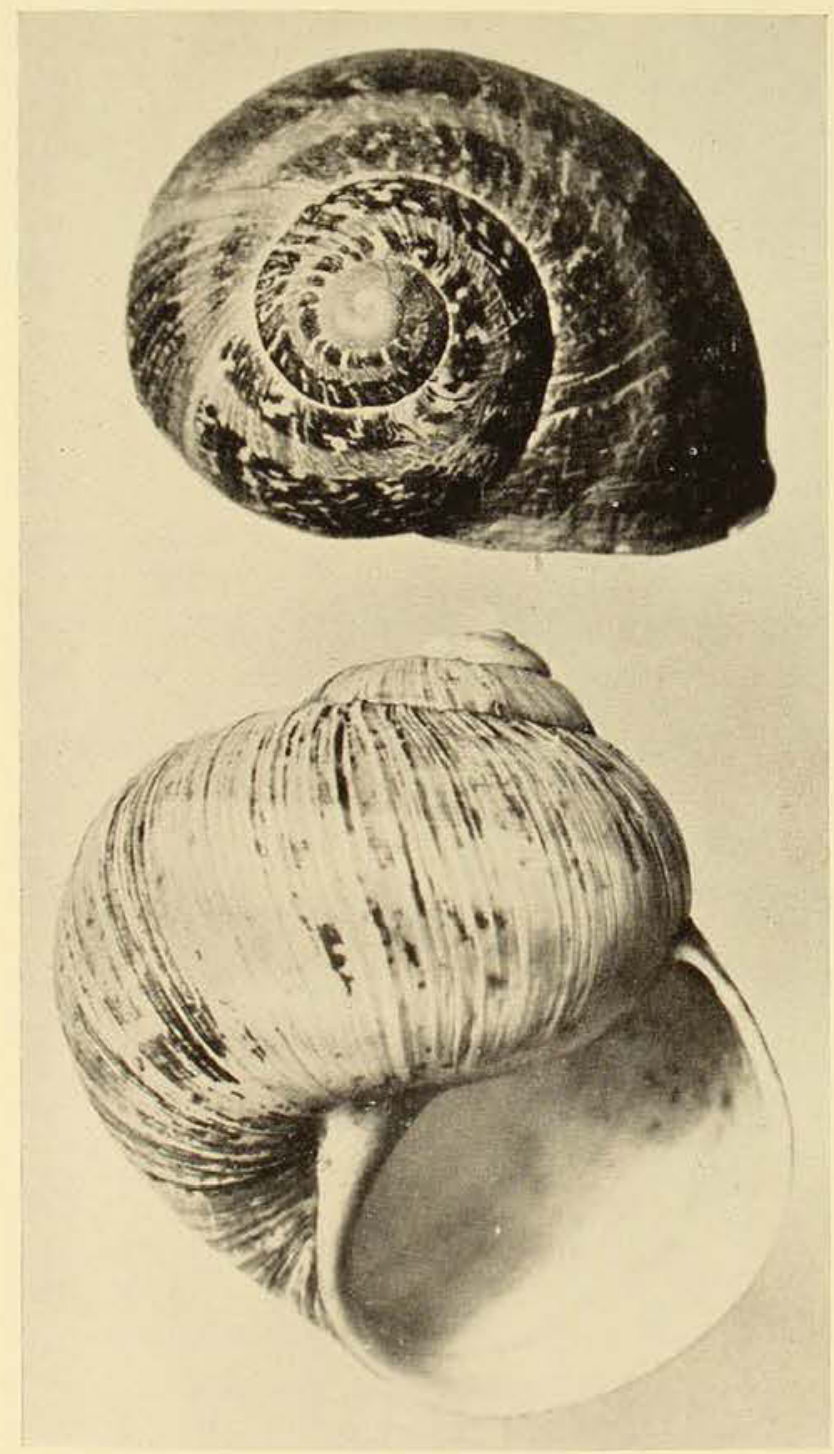

These edible land snails are (top) the common garden snail of England and Australia (Helix aspersa) and the Apple Snail (Helix pomatia).

Both these specimens are from France.

Photo--Howard Hughes. some feet below the boat, as a lure for male squids, which are caught when they cling to the female.

In Spain and Portugal stuffed octopus is sold by delicatessen shops, and octopus fried in batter is sold at Italian seaside cafes. Very young octopus is usually extremely tender, and on the island of Ischia, in the Mediterranean, it is fried and used as filling for sandwiches. In Mediterranean countries cuttlefish are usually cooked in their own ink and canned, and squid are used in a variety of dishes, mainly in casserole form.

The Sydney rock octopus (Octopus cyaneus), when sufficiently tenderised and subjected to suitable pressure cooking, makes fine food.

Finally, in this brief survey of the edible molluses, a word about the famed "escargot" - the snail. Many different kinds of land snails are found throughout the world, most of which are edible. The best-known food snail is the European Apple Snail (Helix pomatia), but the common English (and Australian) garden snail (Helix aspersa) is also widely eaten.

Snails have been a favoured food for thousands of years. The Romans regarded them as potent aphrodisiacs, and cultivated them on specially run snail farms, or cochlearia, where they were fed on sodden wine dregs, bran, flour and various aromatic herbs, as well as the natural vegetation. The Romans also had special spoons, known as cochleare, for eating the snails.

Snails are still cultivated in certain areas of France and Spain, and sold commonly in the market places.

There are many ways of preparing snails for cooking, but the usual method seems to be to starve them for several days at least, following which they are washed in vinegar and salt, rinsed in many changes of water and boiled for several hours with various seasonings. They are served in the shell, with a butter sauce made from a variety of herbs.

Most Sydney residents would have little trouble collecting enough snails for a meal from their gardens, but those not so blessed can now buv canned European Apple Snails, complete with shells in which to serve them! 


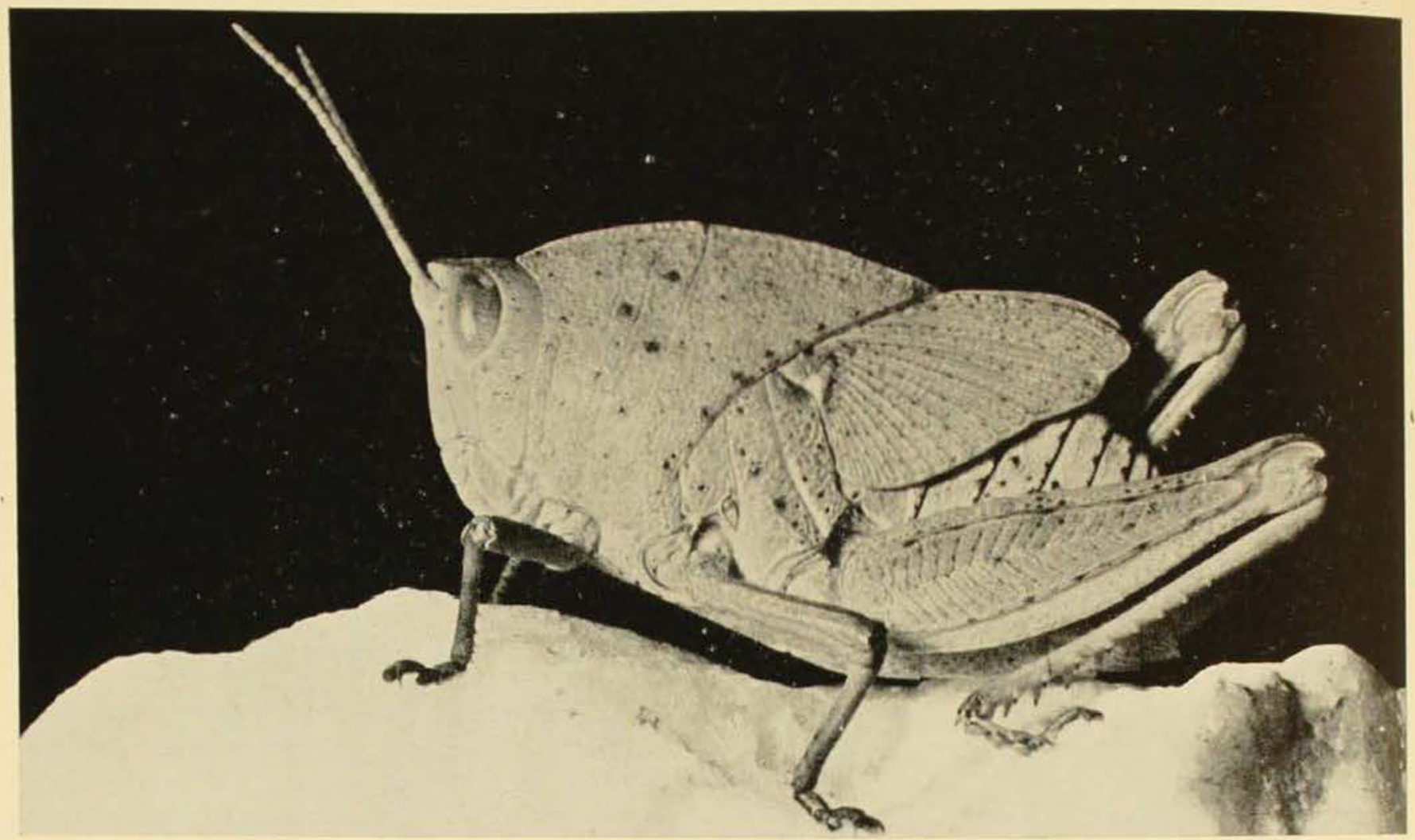

A spinifex grasshopper, one of the 10,000 insects which a Western Australian Museum expedition brought back from the Hamersley Range area.

Photo.-Peter McMillan.

\title{
A MUSEUM EXPEDITION TO THE HAMERSLEY RANGE
}

\author{
By W. D. L. RIDE \\ Director, Western Australian Museum
}

THE Western Australian Museum sent an expedition to the Hamersley Range, one of the most interesting faunal areas in that State, in July, 1958. This expedition resulted in important additions, including about 10,000 insects and more than 500 reptiles, being made to the museum's collection.

The Hamersley Range is a great flattopped mass of non-metamorphosed Precambrian sediments which were laid down on the sea bed more than $500,000,000$ years ago. During subsequent ages, the great mass of rock which was to become the range that we know was raised above the level of the sea, and it now stands above the surrounding plateau in about latitude $22 \mathrm{~S}$., roughly 100 miles inland from the coast of Western Australia.

During the millions of years that the range has been exposed to the sand-laden wind, the rain, and the great ice sheets of the Permian Ice Age, it has become dissected into the broken ramparts that now lie for mile after mile across the arid countryside.

These ramparts are a mixture of great masses of rock intersected by narrow chasms with sheer walls and tumbled screeslopes. Great gorges, like Wittenoom Gorge and Dale Gorge, expose in their sides the horizontally-bedded strata of the sediments which were laid down so many millions of 
years ago sedimentary rocks that are now, in their turn, being slowly broken down again and returned to the seas through the great flood waters of the Fortescue River.

The country around the range is one of vast sheep stations, stations with names which are famous in the wool trade-Millstream, Mulga Downs, Coolawanyah, Hooley and Hamersley, to mention but a few. Many of these are of great size; Millstream for example, is nearly three-quarters of a million acres. The country is very dry and is clothed with spinifex (Triodia) and occasional thickets of Snakewood Mulga (Acacia cuthbertsoni), but through this arid zone runs the channel of the river with its permanent pools and springs of cool water. In some of the gorges of the ranges and in those of the edge of the tableland there is also water. The annual rainfall averages 12 ins., and most of this falls between November and April.

Broadly, this decribes the country into which the Western Australian Museum Hamersley Range Expedition went in July, 1958.

The Hamersley Range was chosen for this expedition because it is one of the most interesting faunal areas in Western Australia where the interaction of the main faunal groups is far from fully understood. These faunal groups inhabit characteristic environments, and in a State where much of the country is extremely arid one would expect a large part of the fauna to be very much like that of most of South Australia, Central Australia and the interior of New South Wales and Queensland. This dry-country fauna is called Eyrean by many biologists after Lake Eyre in Central Australia. In the south-west of Western Australia is another area which is damper and cooler and well forested. This is inhabitated by many animals which show a close affinity with those of south-eastern Australia. This southern fauna is now generally called Bassian. In the far north of Western Australia occurs the third of the State's faunal groups; this is adapted to the tropical conditions which extend right across the northern part of the continent and up into New Guinea. This third fauna is called Torresian (see Serventy and Whittell, "The Birds of Western Australia", pp. 44-60, for a discussion of faunal regions).
In Western Australia a major desert area called the Canning Basin carries the centraldesert environment right out to the sea at the Eighty-mile Beach just to the north of Port Hedland. One might expect that this corridor to the coast, which is ideally suited to an Eyrean fauna, might mark the southern limits of Torresian fauna in the State, but it has long been known that isolated elements of the Torresian fauna occur to the south of the Canning Basin.

\section{Climatic Changes}

There are several ways of explaining the presence of these isolated outliers, but the simplest seems to be to postulate that, in the not-so-distant past, much of Western Australia had a more humid climate. During this period the Torresian animals would have occurred widely, and the fluctuating increases in aridity that have followed this period and culminated in our present arid climate would have extinguished them over much of their former range, leaving only small patches of suitable environments in which a few Torresian elements have remained. It has long been known from the botany and ornithology of the area that the Hamersley Range was likely to be one of these strongholds.

That part of Western Australia which includes the Hamersley Range was first explored by A. C. and F. T. Gregory in 1861, when a small party led by F. T. Gregory made its way up the Fortescue River from Nickol Bay. The Gregorys were interested in natural-history, and they made a number of valuable observations and collected some bird skins, which included the type specimens of the Spotted Bower Bird and the "Spinifex Pigeon". (The diaries of the Gregorys were published in Brisbane in 1884 under the title "Journals of Australian Explorations"). Apart from the specimens collected by this early expedition, only one major collection has been made in the area -by F. Lawson Whitlock, who collected birds there between July and November 1922. (For an account of this trip, see "Emu", 1923, vol. 22, pp. 259-273). Whitlock was collecting for H. L. White, and his specimens are now in the National Museum of Victoria. 


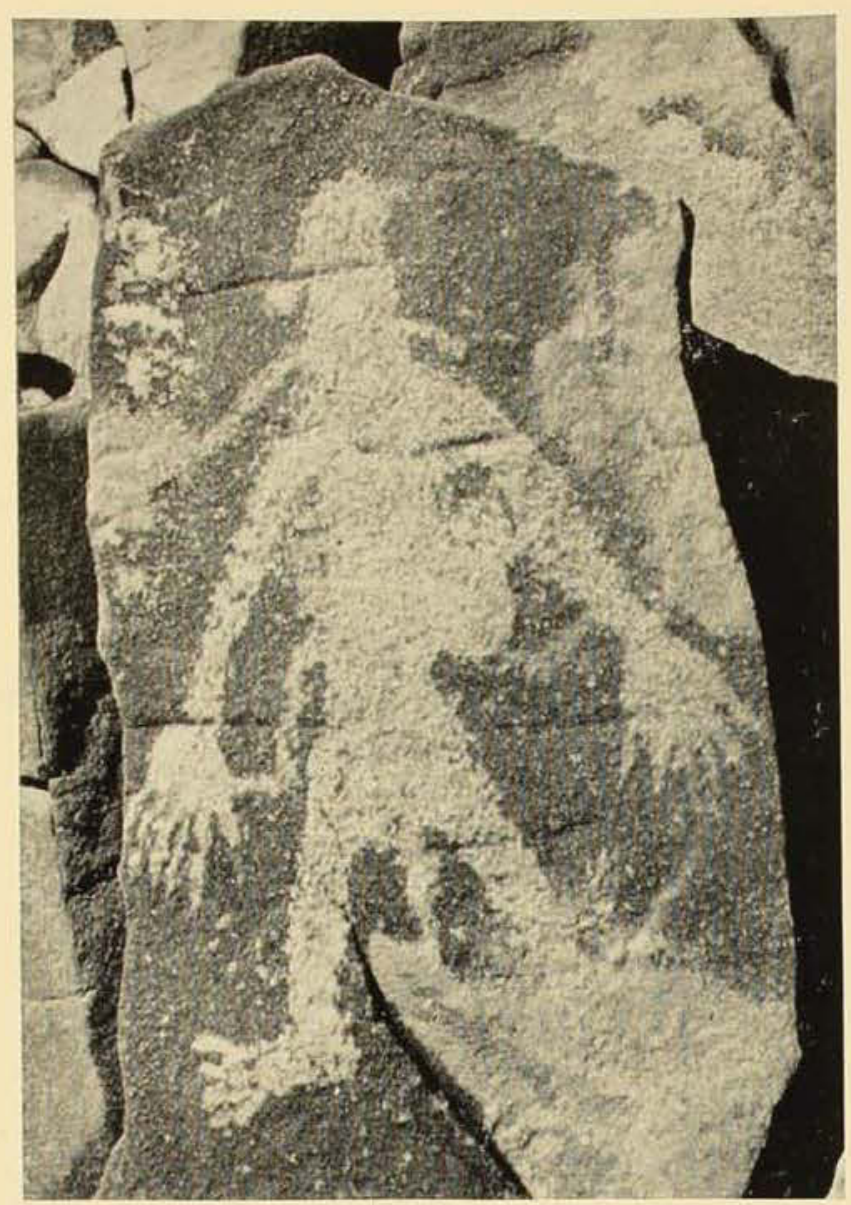

The expedition found an enormous and previouslv unknown gallery of Aboriginal rock carvings on masses of stone on the hillsides above Black Hill Pool (right), at the foot of Mt. Herbert. Above is one of the carvings.

Photos.-Author.
The party which left the Museum in July 1958 was chosen to cover as wide a field of collecting interests as possible. Individual members of the party were to concentrate on their own special fields but, of course, when animals which did not belong to their particular groups presented themselves for capture opportunities were not wasted. Mammals were collected by the author, who was also leader, and by $\mathrm{Mr}$. A. M. Douglas; birds by Dr. G. F. Mees and Mr. K. G. Buller, who also acted as preparator to the party; reptiles and amphibia by $\mathrm{Mr}$. W. H. Butler and Mr. John Mitchell, Curator of Reptiles at the South Australian Museum, who ioined us for the expedition. Fish were collected by Miss Kaye Vollprecht and insects by Mr. Tony Watson and Mr. R. P. McMillan, who also was the cook.

\section{Beautiful Parrots}

As the expedition had only one Landrover it had to divide into two parties; an advance party went up by road and prepared camp for the main party, which was flown in by air. To make the best of the journey, the road party planned to drive straight to Meekatharra from Perth, a dis. tance of 480 miles, and on the succeeding five days to drive 100 miles each day, make camp, and then collect. This was done so that some sort of picture would emerge of the faunas in the 500 miles immediately to

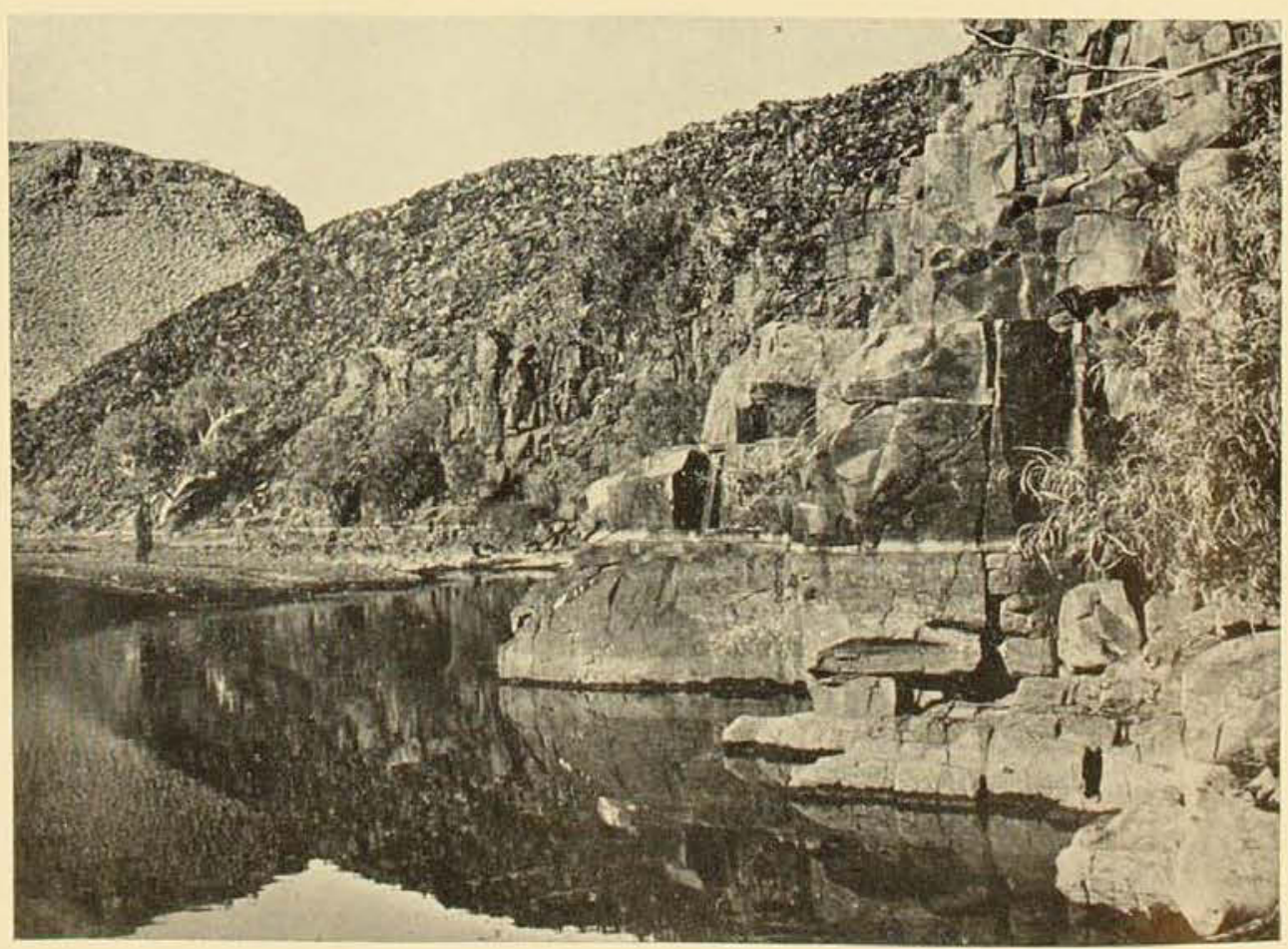


the south of the Hamersley Range country. Unfortunately, the weather was not good and the party was not able to keep strictly to this schedule. Even so, useful material was collected.

At one stop, just north of the Gascoyne River, five Bourke parrots (Neophema bourkii) flew into water in the early morning, and one of them was added to the collection. This beautiful little brown, pink and blue parrot occurs in the barren country between the Ashburton and Murchison watersheds and, although it is not unfamiliar as a cage-bird, wild-caught specimens are not common in Museum collections. It was a good beginning to the bird collection of the expedition.

\section{Rugged Country}

Ten days after the advance party had left Perth by road, the Landrover met the main party on the airstrip at Coolawanyah Station, where, in keeping with the hospitable custom of the country, Mr. Roy Parsons, the owner, insisted that no one should do anything before being fed an enormous breakfast.

The bird's-eye view which the party had had from the MacRobertson Miller DC3 as it flew over the Range in the early morning had a sobering effect on the excursionlike gaiety of the party. In the early morning the great mass of rock which sprawled across the plain, cut through by numerous twisted ravines, looked far too much for a small expedition to tackle successfully. However, after having been duly fortified by the hospitality at Coolawanyah we all felt better, and set off in the Landrover for Millstream Station, which was to be the first of our major collecting localities.

I don't think any of us will ever forget our first sight of the Fortescue River at Millstream. After having spent much of the day driving slowly across the plateau of the tableland, with its hot, dusty plains of grass and spinifex and its rocky breakawavs, we suddenly descended into a valley filled with huge, moisture-loving cadjeputs (Melaleuca leucodendron). Water in enormous quantities swirled around their roots and across the track in front of us, and schools of small fish swam away from under the wheels of the Landrover as we slowly moved through. The air in the valley was cool and damp, an incredible contrast to the heat of the plains only a few hundred yards away. For a brief moment I imagined that I was breathing the damp mists of the Thames Valley, which form such a vivid part of my undergraduate memories of Oxford.

Millstream is a biologist's paradise. There, the Fortescue River is fed by a number of permanent springs, which fill the deep pools that lie in the valley. This abundance of water has produced a tropical environment in the midst of arid surroundings. Here were palm trees (Livistona alfredi), water birds and fruit bats (Pteropus scapulatus). This is where, on June 6, 1861, Francis Gregory named the river: " . . . here was first observed very handsome fan-palms, growing in topes, some of them attaining to the height of forty feet and twenty inches in diameter, the leaves measuring eight to ten feet in length. The river had again opened into deep reaches of water, and contained abundance of fish resembling cobblers, weighing four and five pounds each ... . I named the river the Fortescue .

We, too, caught cobbler in large numbers, and seven other species besides. Strange to relate, in spite of the fact that the cobbler was mentioned so clearly by Gregory in his diaries of nearly 100 years ago, no specimens have been collected for museums since, and it even looks as though it may prove to be an as-yet unnamed species.

A large number of interesting species of birds were obtained here, among them the small golden-headed Fantail Warbler (Cisticola exilis). This species is a typical Torresian form, which occurs in New South Wales, Queensland, the Northern Territory and the Kimberley Division, but has only been recorded south of the Canning Basin at the pools at Millstream. The most characteristic birds of this river country were the omnipresent "Bush Canary" (Meliphaga penicillata - White-plumed Honeyeater and the Blue-winged Kookaburra (Dacelo leachii).

After we had been at Millstream for a few days we decided on me details of the methods we were to adopt in order to 
sample the fauna of the 2.000 or so square miles in which we had chosen to work. Most important of all, it was necessary to avoid spreading our efforts too thinly over too much ground, so we concentrated on collecting in five major areas, which were deliberately chosen to give us as wide a range of different habitats as possible.

These were: the valley of the Fortescue River at Millstream, with its tropical forest and plentiful water: the streams at the head of the watershed of the Sherlock and George Rivers which flow away to the north from the tableland, because they belong to a drainage system independent of that of the Fortescue; the arid spinifex plains and low break-aways of Tambrey Station, as being typical of the arid tableland; one of the deep dry gorges of the Range itself; and, finally, the edge of the escarpment where the tableland plunges down to the coastal plain below.

\section{Aboriginal Rock-carvings}

The foot of the tableland could easily be reached from Millstream Station, and a collecting party worked there from the main base at the station. The fauna there was largely the same as that we were to find later among the spinifex of Tambrey, but the Grey-headed Honeyeater (Meliphaga keartlandi) was common in the shrubs which grew in the small rocky gorges of the high break-aways. Everywhere we looked among the spinifex clumps there were pairs of the small and beautiful "Spinifex Pigeon" (Lophophaps ferruginea - the Red-plumed Pigeon). Gregory had obtained the type of this species on his journey here in 1861 .

The most interesting of the finds which we made there, close to where the road to Roebourne climbs down over the edge of $\mathrm{Mt}$. Herbert, was an enormous, and previously unknown, gallery of Aboriginal rock carvings. The Aboriginal people had gathered for many generations at a pool of permanent water in the bed of a stream, and the great masses of stone on the hillsides above the water were covered with their pictures. This pool was at the edge of the territory of the Injubundi people. who, only 20 years ago, lived in large numbers on the tableland. Apart from a mere handful who have stayed on the stations, the people have now left their tribal lands, and Malcolm, our Injubundi guide, could tell us nothing about the carvings. He said that they were made by the "old people".

After 10 days at Millstream, the base camp was moved to Tambrey Station, which now forms part of Coolawanyah. The empty homestead was placed at our disposal by the joint owners, Mr. Roy Parsons and Sir Edward Lefroy, and during the few days of torrential rain that followed the move we were more than grateful for the substantial home, which had been strongly built from an adobe of termite mounds and sheeps' wool. The homestead stands in a small valley surrounded by low break-aways, and clumps of spinifex dot the red earth for miles in all directions.

The break-aways contain caves, and it was here that we caught most of the bats collected on the expedition - the Ghost Bat (Macroderma gigas), the Free-tailed Bat (Taphozous georgianus), the Little Bat (Eptesicus pumilus) and, from among the leaves of the Ghost Gums, Gould's Wattled bat (Chalinolobus gouldi). In the spinifex we obtained good series of Carter's spinifexbird (Eremiornis carteri), the Rufuscrowned Emu Wren (Stipiturus ruficeps) and the Striated Grass Wren (Amytornis striatus). These small birds were exceedingly difficult to collect, and we all know now why they are rare in museum collections.

\section{Specimens for Museum}

The end of the tenth day on Tambrey marked the end of the expedition to the Hamersley Range country-an expedition that resulted in additions to the collection of the Western Australian Museum by about 10,000 insects, more than 500 reptiles of 52 species, 290 birds of 75 species, several hundred fish of eight species and about 50 mammals of 13 species. But just as important as the material specimens which returned to Perth was the field knowledge that the biologists had gained. A great mass of important biological detail has been collected which will be used to give further meaning to the specimens. 


\section{THE WAY OF LIFE OF THE SLATER}

By J. LE GAY BRERETON

Department of Zoology, University of New England, N.S.W.

SLATERS have not generally attracted the attention of naturalists, and lack the beauty of such commonly-studied animals as birds, butterflies and shells. Nevertheless, this common invertebrate becomes a fascinating animal when one asks oneself the right questions about it and looks at it more closely.

Slaters are members of the Phylum Arthropoda, which includes the following major groups of related animals:-

(1) Onychophora-e.g. Peripatus, an animal considered a link between the earthworm group and the Arthropoda. Terrestrial.

(2) Trilobita-extinct forms.

(3) Crustacea-shrimps, crabs, lobsters and slaters; they are all found in fresh-water or marine habitats except some of the slaters, which are terrestrial.

(4) Myriapoda-centipedes, millipedes. Terrestrial.

(5) Insecta - a huge group containing more species than all the rest of the animal kingdom put together. These are the insects, characterised by three pairs of legs. Terrestrial.

(6) Arachnida - scorpions, spiders, mites. Terrestrial.

\section{Seven Pairs Of Legs}

The slaters are the only group of the Crustacea which have become fully terrestrial. Many of their close relatives are marine or in freshwater. Most people know them as sow-bugs, pill-bugs or woodlice.

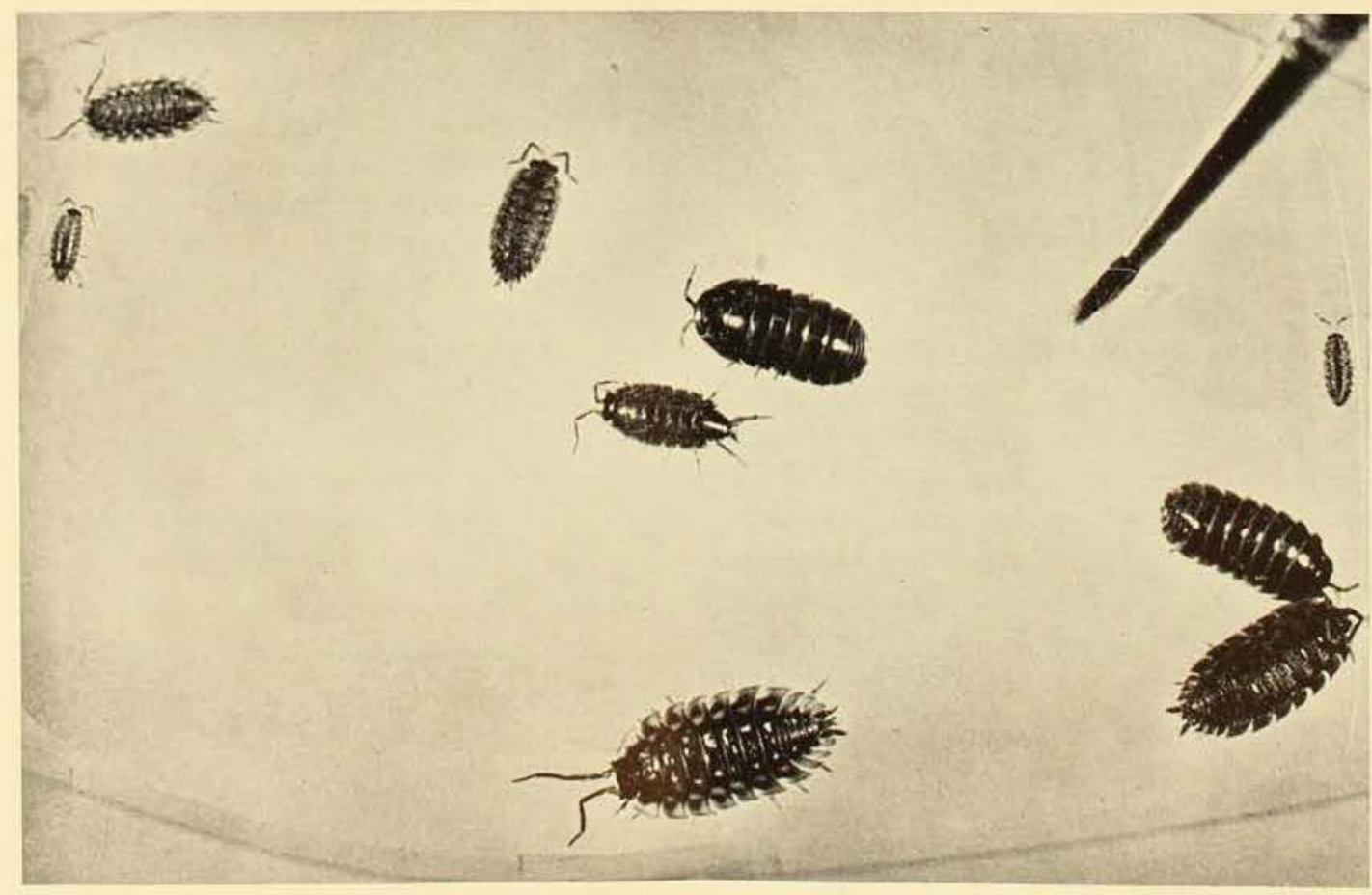

Some common slaters of world-wide distribution. Left: Oniscus asellus (top) and Philoscia muscorum. Centre: Porcellis scaber. Armadillidium vulgare, P. muscorum, $O$. asellus. Right: $P$. Scaber (young), A. vulgare, $O$. asellus.

Photo.-D. Kempson 
They are flattened animals, up to about half-an-inch long, with seven pairs of legs and one pair of visible antennae. Some of them can roll up into a ball. Some breathe by means of plates under the abdomen, and in the most completely terrestrial forms little tubes, like the trachea of insects, are found in these plates. They give a white opaque effect to the plates which can be seen with the naked eye.

While these animals are quite well known to the general public because they are found around houses and in gardens, it is not generally realised that probably the proper place in nature for these apparently semidomestic species is the deciduous woodland of Europe.

Four species occur there, seemingly in equilibrium with each other. At this point we might well ask if they obey that important hypothesis of Charles Darwin that closely related species generally have very similar ways of life and should not, therefore, be able to co-exist. One species, he said, is bound to be superior in its adaptation to its environment, and it should become more common at the expense of the others. The others would be expected to do one of three things: $(a)$ become dominant in a part of the habitat to which they are better adapted than the "superior" one; (b) become adapted to a quite different habitat, or (c) become extinct.

\section{Mystery Story}

When we look at the common species of slaters in European woodland we find that Trichoniscus species are found chiefly in the dead leaves and dead wood lying on the ground, Philoscia muscorum is in the dead leaves, Oniscus asellus is under stones and dead wood or in crevices in trees, while Porcellio scaber also is found on trees. There is considerable overlap here. One senses a mystery story: I wish I could write the last chapter. All we can say is that much more study is required before we can decide about exactly what is happening. What is needed is a fairly accurate knowledge of the way of life, or ecology, of all these species. but so far it is known only for Porcellio scaber.

This species appears to live all its life on trees. In winter in the Northern hemisphere it creeps into the moss layer at the

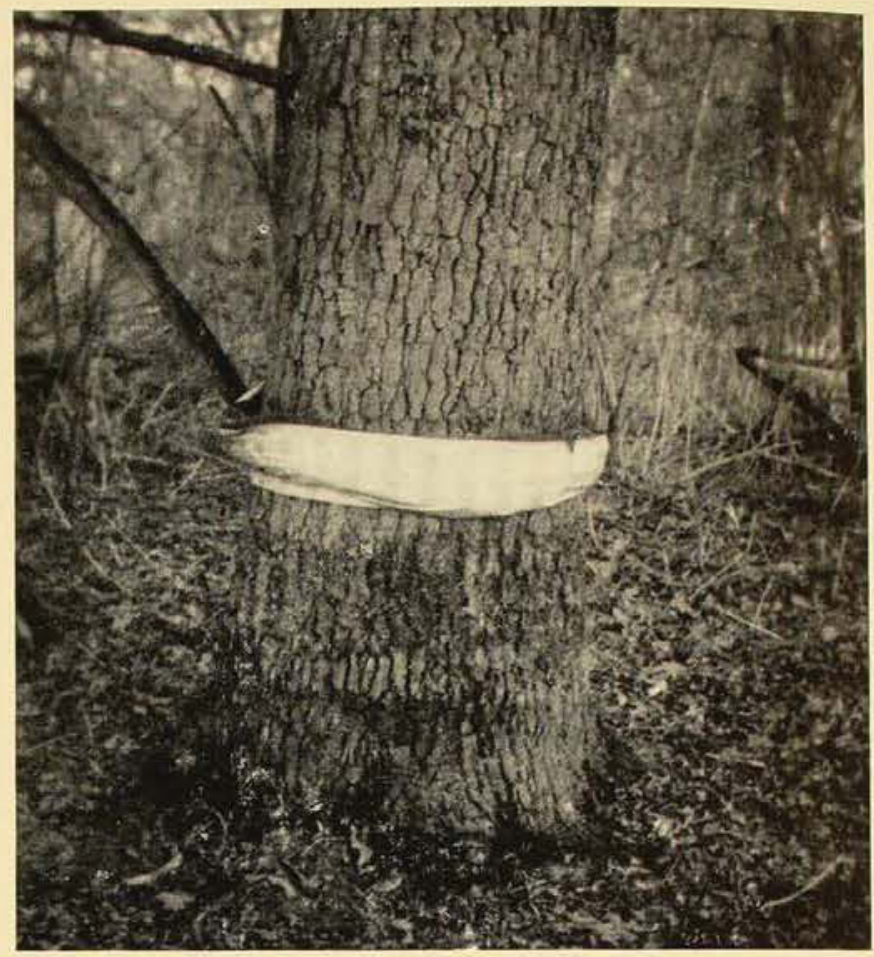

A simple trap - a band of plastic stuffed with hessian - for catching slaters on their migration down a tree in autumn.

Photo.-Author

base of the trees. In spring it moves to the topmost twigs and branches. Here the young are released from the brood pouch under the thorax, where the eggs are carried. Incidentally, it is this carriage of the eggs under the female that has permitted the slaters to colonise dry land. Some of the crabs live on exceedingly dry sand-dunes, but they are not fully terrestrial for they have to return to the sea to breed.

The migratory movement of Porcellio scaber up and down the trees takes place at night. This can only be known by making studies during the day and night in all seasons of the year. It is slightly like trying to find out the behaviour pattern of students in a University College. Sampling in the University lecture rooms and laboratories will give large numbers in the day time and low numbers at night. Conversely, sampling the College will disclose that the numbers are low in the day time and high at night. Then, when term ends, numbers will fall in both places. In the same sort of way a picture of the changes in numbers and distribution of Porcellio scaber was built up. 
As a check on the deduction that a seasonal migration was taking place a simple trap was built which would catch slaters on their way down the tree in the autumn. This was a band of plastic stuffed with hessian. A 12-inch wide band of sticky material, repulsive to invertebrates, was placed below, to prevent any animals entering the trap from below (see illustration). At the end of the autumn the hessian was brought into the laboratory and, by slowly drying it, the animals were expelled into a vessel.

In this way not only was it possible to prove that migration took place, but a fair estimate of the total population of trees was provided. Further still, this permitted estimates of the age-distribution of the population. Data on birth-rate and survival were also obtained, so it was possible to make calculations and predictions about the population similar to those made for human populations, where the data is so much easier to obtain. In this way a fairly complete knowledge of the temporal changes in distribution and abundance of this species was obtained. However, as we have seen, if the processes of evolution are to be understood much more needs to be known, in this case especially, about the way of life of the other species of slaters found in this woodland.

\section{Much Work To Be Done On Slaters}

Unfortunately, all this is about slaters in an English woodland. We have the same common ones here around human habitation, but in our natural communities they are different. A very great deal needs to be found out about them, and much can be done by naturalists. It never fails to cheer me when I am reminded that some of the best work in biology has been done by amateurs and people trained for other work. Darwin himself was not trained as a biologist, and Gregor Mendel was a graduate in the physical sciences.

So I suggest that for detailed studies of the way of life of animals and for zoogeographic studies - in fact, if you want to study the problem of evolution - you cannot do better than slaters. Moreover, once started you will find them quite as aesthetically stimulating as birds, butterflies or shells.

\section{Obituary \\ Anthony Musgrave, F.R.E.S., F.R.Z.S.}

\begin{abstract}
A GENTLEMAN and a scholar. This phrase is fittingly applied to $\mathrm{Mr}$. Anthony Musgrave, Curator of Insects and Arachnids at the Australian Museum, Sydney, whose sudden death on 4th June, 1959. at the age of 64 , is mourned by his colleagues on the Museum's staff and by a wide circle of friends.
\end{abstract}

Only two evenings before his death $\mathrm{Mr}$. Musgrave had delivered the Froggatt Memorial Lecture at the Naturalists' Society of New South Wales in his usual highspirited way. The lecture epitomised his main interests: his zealous devotion to natural history: painstaking study of all aspects of his subject matter (historical, geological, zoological and botanical); his extensive reading and verification of sources, and his ability to produce lantern slides of great technical excellence and beauty. He had studied art under Julian Ashton, and used to illustrate his early scientific papers with his own drawings. He was active in the field and almost every year would spend some time in the bush collecting insects, writing detailed observations and photographing anything likely to be of later use.

$\mathrm{Mr}$. Musgrave was born at Cooktown, Queensland, on 9th July, 1895, his father, Captain the Hon. Anthony Musgrave, C.M.G., being Deputy Commissioner, and later Government Secretary of British New Guinea.

He joined the staff of the Museum as a cadet on 7th February, 1910, and, after a year in the library, was appointed assistant 
to the then entomologist, W. J. Rainbow. In 1920, after Mr. Rainbow's death, Mr. Musgrave was appointed entomologist, a title later altered to Curator of Insects and Arachnids.

Mr. Musgrave joined the Royal Zoological Society of New South Wales in 1919 or 1920, was a member of its Council from 1920 to 1935, and was elected President in 1929-30 and a Fellow in 1933. He was also a Fellow of the Royal Entomological Society of London, and a member of the Linnean Society of New South Wales and the Royal Australian Historical Society. He served on the Council of the last-named in 1956 and 1957.

He had a wide knowledge of insects and arachnida, but chose to specialise in Hemiptera and Diptera (notably Nycteribudae), spiders and ticks. Above all, he was interested in the vast literature on Australasian and Pacific entomology. His bibliographical work was amazingly detailed. Not only would he personally check every reference to every available book and paper, but he determined exact dates of publication and recorded brief biographies of their authors and the routes and dates of scientific expeditions on which insects and arachnida were collected.

Mr. Musgrave's monumental "Bibliography of Australian Entomology, 1775 1930, with biographical notes on authors and collectors" was published by the Royal Zoological Society of New South Wales in 1932 and was kept up-to-date by him on cards.

It is hoped that it will be possible to publish not only the manuscript addenda to that work but also his card-index bibliography of Pacific entomology and his maniscript check-lists of Australian arachnids and weevils.

He also compiled, for about 20 years, all the zoological entries for "Australian Science Abstracts" until they ceased publication in 1957.

A bibliography of his writings is now being prepared for publication. Here we may merely note that his first article, concerning "Insects on Wattles", appeared in the "Australian Naturalist" (April, 1911). Others down to 1930 are listed in his bibliography of 1932 .

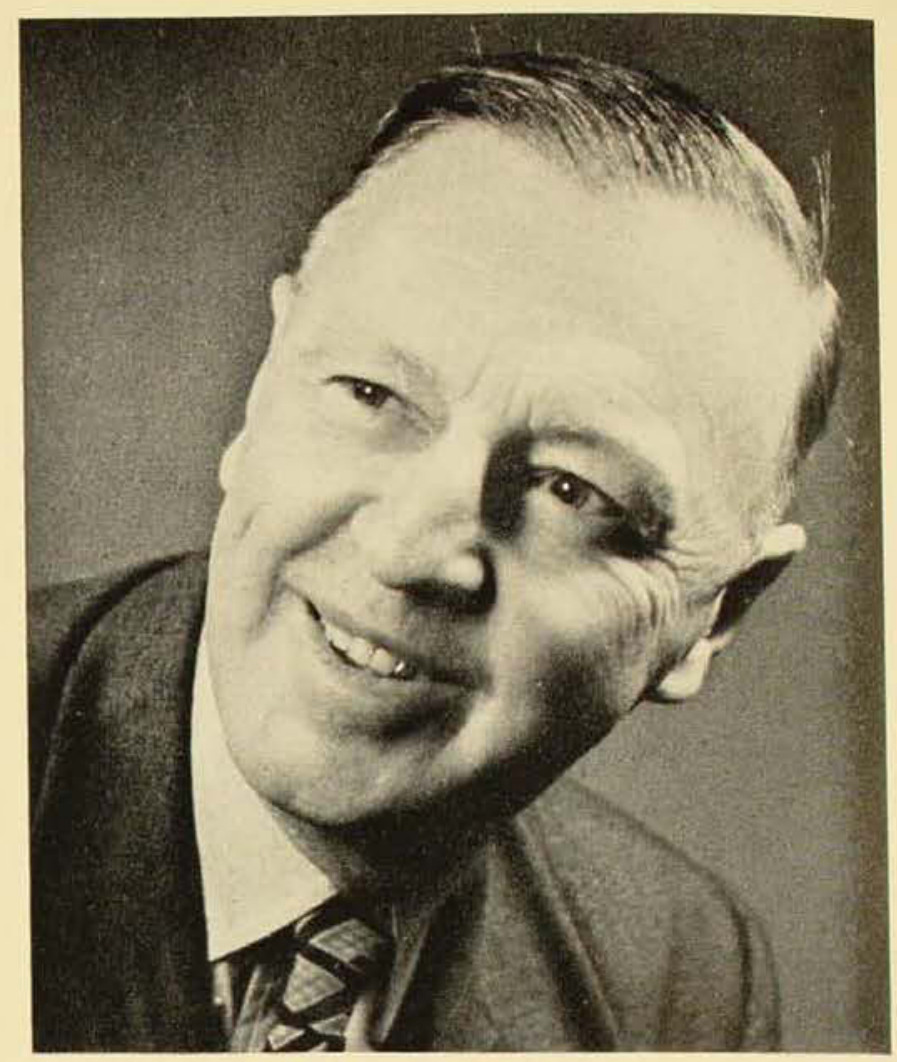

The late Anthony Musgrave.

Mr. Musgrave wrote articles for both the first (1925) and second (1958) issues of the Australian Encyclopaedia, and contributed many others to the Australian Museum Magazine and the proceedings of scientific societies. He wrote a history of his native Cooktown for the Royal Australian Historical Society, and was a joint author of the great Index (1958) to the articles, authors and illustrations in the first 42 volumes of that society's journal.

Though he disliked press publicity and declined radio and television interviews, he identified many thousands of insect and spider specimens for Museum visitors and wrote many Museum leaflets for distribution to the public.

He was widely respected for his helpfulness to people interested in natural history and for his many private acts of charity and kindness.

He was fond of good plays and music. and knew by heart and sang many of the Gilbert and Sullivan lyrics, which appealed to his rich sense of humour.

Mr. Musgrave never married. $\mathrm{He}$ is survived by his sister, Mrs. Frances Hatton, a niece, Miss Elizabeth Hatton, and cousins, to whom sympathy is expressed in their great loss.-G.P.W. 